ARTICLE

\title{
The stability of P2-layered sodium transition metal oxides in ambient atmospheres
}

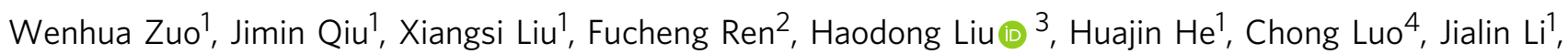
Gregorio F. Ortiz (1) ${ }^{1,5}$, Huanan Duan ${ }^{6}$, Jinping Liu (1) ${ }^{7 凶}$, Ming-Sheng Wang $\mathbb{C}^{4}{ }^{4}$, Yangxing $\mathrm{Li}^{8}$, Riqiang Fu (1) ${ }^{9}$ \& Yong Yang (iD) $1,2 \otimes$

Air-stability is one of the most important considerations for the practical application of electrode materials in energy-harvesting/storage devices, ranging from solar cells to rechargeable batteries. The promising P2-layered sodium transition metal oxides (P2$\mathrm{Na}_{x} \mathrm{TmO}_{2}$ ) often suffer from structural/chemical transformations when contacted with moist air. However, these elaborate transitions and the evaluation rules towards air-stable P2$\mathrm{Na}_{x} \mathrm{TmO}_{2}$ have not yet been clearly elucidated. Herein, taking $\mathrm{P} 2-\mathrm{Na}_{0.67} \mathrm{MnO}_{2}$ and $\mathrm{P} 2-$ $\mathrm{Na}_{0.67} \mathrm{Ni}_{0.33} \mathrm{Mn}_{0.67} \mathrm{O}_{2}$ as key examples, we unveil the comprehensive structural/chemical degradation mechanisms of $\mathrm{P} 2-\mathrm{Na}_{\mathrm{x}} \mathrm{TmO}_{2}$ in different ambient atmospheres by using various microscopic/spectroscopic characterizations and first-principle calculations. The extent of bulk structural/chemical transformation of $\mathrm{P} 2-\mathrm{Na}_{x} \mathrm{TmO}_{2}$ is determined by the amount of extracted $\mathrm{Na}^{+}$, which is mainly compensated by $\mathrm{Na}^{+} / \mathrm{H}^{+}$exchange. By expanding our study to a series of $\mathrm{Mn}$-based oxides, we reveal that the air-stability of $\mathrm{P} 2-\mathrm{Na}_{\mathrm{x}} \mathrm{TmO}_{2}$ is highly related to their oxidation features in the first charge process and further propose a practical evaluating rule associated with redox couples for air-stable $\mathrm{Na}_{x} \mathrm{TmO}_{2}$ cathodes.

\footnotetext{
${ }^{1}$ State Key Laboratory for Physical Chemistry of Solid Surfaces, and Department of Chemistry, College of Chemistry and Chemical Engineering, Xiamen University, 361005 Xiamen, People's Republic of China. ${ }^{2}$ School of Energy Research, Xiamen University, 361005 Xiamen, People's Republic of China. ${ }^{3}$ Department of NanoEngineering, University of California San Diego, La Jolla, CA 92093, USA. ${ }^{4}$ Department of Materials Science and Engineering, College of Materials, Xiamen University, Xiamen, 361005 Fujian, People's Republic of China. ${ }^{5}$ Departamento de Química Inorgánica e Ingeniería Química, Instituto Universitario de Investigación en Química Fina y Nanoquímica, Universidad de Córdoba, Campus de Rabanales, Edificio Marie Curie, E-14071 Córdoba, Spain. ${ }^{6}$ State Key Laboratory of Metal Matrix Composites, School of Materials Science and Engineering, Shanghai Jiao Tong University, 200240 Shanghai, P. R. China. ${ }^{7}$ School of Chemistry, Chemical Engineering and Life Science and State Key Laboratory of Advanced Technology for Materials Synthesis and Processing, Wuhan University of Technology, 430070 Wuhan, Hubei, People's Republic of China. ${ }^{8} 4135$ Belle Meade Circle, 28012 Belmont, North Carolina, USA. ${ }^{9}$ National High Magnetic Field Laboratory, 1800 E. Paul Dirac Drive, Tallahassee, FL 32310, USA. ${ }^{凶}$ email: liujp@whut.edu.cn; yyang@xmu.edu.cn
} 
ractical application is always the ultimate goal for state-ofthe-art technologies and devices, such as perovskite solar cells, thin-film transistors, and electrochemical batteries ${ }^{1}$. Air-stability is undeniably one of the key issues that researchers should consider, because any air-instable compounds must be prepared, stored and assembled in dry or even inert atmospheres, leading to an increase in expense and can even jeopardize whether they are successfully commercialized.

Sodium ion batteries (SIBs) promise the potential for largescale grid storage, due to the high abundance and wide distribution of $\mathrm{Na}$ sources as compared to their lithium counterparts $^{2-4}$. Among various sodium storage cathodes, layered sodium transition metal oxides $\left(\mathrm{Na}_{\mathrm{x}} \mathrm{TmO}_{2}\right)$ have gained significant attention owing to their great variety of compositions, ease of scalable preparation and high reversible specific capacity ${ }^{5}$. In the past forty years ${ }^{6,7}$, the $\mathrm{Na}_{\mathrm{x}} \mathrm{TmO}_{2}$ family has been greatly enriched not only thanks to the tremendous efforts toward superior cathodes with higher energy density and more stable structures $^{8-10}$, but has also benefited from the development of electrolytes and characterization techniques ${ }^{11-14}$. Nonetheless, $\mathrm{Na}_{\mathrm{x}} \mathrm{TmO}_{2}$ electrodes are still haunted by three major challenges, i.e. irreversible phase transitions during cycling, insufficient electrochemical performances and air/moisture instability ${ }^{5,15}$. The undesired structural transformations in charge/discharge processes, such as $\mathrm{P} 2-\mathrm{O} 2$ in $\mathrm{Na}_{0.67} \mathrm{Ni}_{0.33} \mathrm{Mn}_{0.67} \mathrm{O}_{2}{ }^{16-20}, \mathrm{P} 2-\mathrm{P} 2$ ' in $\mathrm{Na}_{0.67} \mathrm{MnO}_{2}{ }^{10,21-23}$ and O3-P3 in $\mathrm{NaNi}_{0.5} \mathrm{Mn}_{0.5} \mathrm{O}_{2}{ }^{24}$, can be suppressed or delayed by element substitution, thus resulting in improved cycling stability and rate capability. The contact between air-instable $\mathrm{Na}_{\mathrm{x}} \mathrm{TmO}_{2}$ and moisture-air usually produces cracks $^{25}$, electrical insulation species ${ }^{26}$, and hydration phases ${ }^{27}$, which result in a shorter lifetime and poorer rate capability of the exposed layered oxides ${ }^{28-30}$. Therefore, air-stability is considered an important factor to evaluate a qualified $\mathrm{Na}_{\mathrm{x}} \mathrm{TmO}_{2}$ electrode ${ }^{31-33}$.

Recently, Manthiram's group reported that $\mathrm{O} 3-\mathrm{NaNi}_{0.7} \mathrm{Mn}_{0.15}$ $\mathrm{Co}_{0.15} \mathrm{O}_{2}$ reacts with $\mathrm{H}_{2} \mathrm{O}$ and $\mathrm{CO}_{2}$, generating $\mathrm{NaOH}, \mathrm{Na}_{2} \mathrm{CO}_{3}$, $\mathrm{Na}_{2} \mathrm{CO}_{3} \cdot \mathrm{H}_{2} \mathrm{O}$ and $\mathrm{NiO}$ on the particle surfaces and leading to declined electrochemical performances ${ }^{26}$. However, these degradation (Ni loss) reactions have not yet been extensively observed in $\mathrm{Ni}$-poor/Ni-free $\mathrm{Na}_{\mathrm{x}} \mathrm{TmO}_{2}$ materials, whether exposed to air or immersed in water ${ }^{34,35}$. Unlike degradation, $\mathrm{H}_{2} \mathrm{O}$ insertion is widely encountered in $\mathrm{P} 2-\mathrm{Na}_{\mathrm{x}} \mathrm{TmO}_{2}$ electrodes and can be easily distinguished by X-ray diffraction (XRD), because the intercalation of $\mathrm{H}_{2} \mathrm{O}$ expands the interlayer distance of the $\mathrm{Na}^{+}$layers from $\sim 5$ to $\sim 7 \AA$ and even up to $\sim 9 \AA^{36-38}$. Kubota et al. proposed the $\mathrm{Na}^{+} / \mathrm{H}^{+}$exchange mechanisms in O3-type $\mathrm{NaMeO}_{2}$ oxides ${ }^{39}$ and Rojo's group further identified the presence of $\mathrm{H}^{+}$in the $\mathrm{Na}^{+}$ layers using a neutron powder diffraction technique ${ }^{30}$. In addition, in the presence of $\mathrm{H}_{2} \mathrm{O}, \mathrm{CO}_{2}$ was believed to get inserted into the transition metal layers of $\mathrm{P} 2-\mathrm{Na}_{2 / 3} \mathrm{Fe}_{0.5} \mathrm{Mn}_{0.5} \mathrm{O}_{2}{ }^{28}$. These works provide valuable insights into the structural evolutions of $\mathrm{Na}_{\mathrm{x}} \mathrm{TmO}_{2}$ upon air-exposure. However, rational connections between these intertwined reactions, especially as to why and when the water molecules insert into the $\mathrm{Na}^{+}$layers, and which factor determines the extent of the structural transformation have not been thoroughly studied yet.

Fundamental understanding of structural/chemical evolutions in moisture is not only critical for the employment of $\mathrm{Na}_{\mathrm{x}} \mathrm{TmO}_{2}$ as electrodes in both organic and aqueous SIBs, but also provides guidance to the fabrication and application of layered transition metal oxides in other battery systems, such as the favorable $\mathrm{Ni}$ rich $^{40-43}$ cathodes for lithium ion batteries. For layered sodiumbased oxides, it is widely recognized that the air-instability in $\mathrm{P} 2$ type oxides is much more severe than that in O3-type $\mathrm{Na}_{\mathrm{x}} \mathrm{MnO}_{2}{ }^{5}$. Herein, based on the $\mathrm{P} 2-\mathrm{Na}_{0.67} \mathrm{MnO}_{2}$ and $\mathrm{P} 2-\mathrm{Na}_{0.67} \mathrm{Ni}_{0.33} \mathrm{Mn}_{0.67} \mathrm{O}_{2}$ oxides, we unearth the underlying science that triggers the hydration of $\mathrm{P} 2-\mathrm{Na}_{\mathrm{x}} \mathrm{TmO}_{2}$, apply unique solid-state nuclear magnetic resonance techniques (ss-NMR) to provide solid evidence for $\mathrm{H}^{+}$ insertion, analyze critical factors that influence the hydration, and outline the structural and chemical evolution mechanisms of $\mathrm{P} 2-\mathrm{Na}_{\mathrm{x}} \mathrm{TmO}_{2}$ oxides upon air exposure. Importantly, the surface-sensitive time-of-flight secondary ion mass spectroscopy (TOF-SIMS) results reveal that the $\mathrm{CO}_{2}$ cannot insert into the layered structure. Our results indicate that $\mathrm{Na}^{+} / \mathrm{H}^{+}$exchange, rather than $\mathrm{O}_{2}$ oxidation, dominates the compensation of extracted $\mathrm{Na}^{+}$and the hydration is closely related to the contents of remaining $\mathrm{Na}^{+}$ions in the structure. The critical sodium content $\boldsymbol{n}_{\boldsymbol{c}}$ is therefore proposed to evaluate whether $\mathrm{H}_{2} \mathrm{O}$ is able to intercalate into the sodium layers. In addition, the study of a series of $\mathrm{P} 2-\mathrm{Na}_{\mathrm{x}} \mathrm{TmO}_{2}$ oxides indicates that the air-stability is closely associated with the voltage features of the charge process in the first cycle, and a practical principle related to the redox couple in the $1^{\text {st }}$ cycle is thus proposed to evaluate the airstability of $\mathrm{Na}_{\mathrm{x}} \mathrm{TmO}_{2}$. These new insights into the degradation mechanisms upon air-exposure will facilitate the development of practical layered $\mathrm{Li} / \mathrm{Na} / \mathrm{K}$ transition metal oxides.

\section{Results}

Features of hydration phases. To investigate the air-stable mechanisms, the structures and characterizations of hydration phases should be clarified first. The $\mathrm{Na}_{0.67} \mathrm{MnO}_{2}$ sample attained by solid-state reaction exhibits a typical P2 structure (space group: $P 6_{3} / \mathrm{mmc}$ ) with a layer spacing of $\sim 5.5 \AA$ (Fig. 1), according to the powder X-ray diffraction (XRD) patterns in Supplementary Fig. 1a. The commonly reported hydration impurity phase in the $\mathrm{Na}_{\mathrm{x}} \mathrm{TmO}_{2}$ is birnessite $27,30,37$, whose structure is very similar to that of $\mathrm{P} 2-\mathrm{Na}_{0.67} \mathrm{MnO}_{2}$, except the presence of extra water molecules in the sodium layers and a broader interlayer distance



Fig. 1 Structural illustration of water insertion. Schematic illustration of $\mathrm{P} 2-\mathrm{Na}_{0.67} \mathrm{MnO}_{2}$, birnessite, and buserite phases. 
of $7.1 \AA$. With further $\mathrm{H}_{2} \mathrm{O}$ insertion, the buserite phase with layer spacing of $\sim 9.1 \AA$ can be identified (Fig. 1 and Supplementary Fig. 1a). In addition to the difference in the interlayer spacing, the birnessite and buserite phases possess a different pattern of $\mathrm{Na}^{+}$and $\mathrm{H}_{2} \mathrm{O}$ arrangements in the sodium layers. For birnessite $\left(\left\{\mathrm{Na}_{0.30} \bullet\left(\mathrm{H}_{2} \mathrm{O}\right)_{0.45}\right\} \mathrm{MnO}_{2}\right)$, according to the Rietveld refinement results ${ }^{44}$ (Supplementary Table 1 and Fig. 1b) and the neutron powder diffraction patterns $(\mathrm{NPD})^{45}$, the $\mathrm{O}$ ion of inserted $\mathrm{H}_{2} \mathrm{O}$ molecule locates at the same site of $\mathrm{Na}^{+}$; while for the highly hydrated buserite $\left(\left\{\mathrm{Na}_{0.24} \bullet\left(\mathrm{H}_{2} \mathrm{O}\right)_{2.1}\right\} \mathrm{MnO}_{2}\right)$, the $\mathrm{Na}^{+}$ ions are sandwiched by the inserted $\mathrm{H}_{2} \mathrm{O}$ molecules ${ }^{46,47}$, as illustrated schematically in Fig. 1. Since buserite is seldom encountered in the moisture-exposed $\mathrm{Na}_{\mathrm{x}} \mathrm{TmO}_{2}$, the hydration phase discussed below is referred to birnessite phase unless otherwise specified. It should be further pointed out that the $\mathrm{Na}^{+}$content in hydrated $\mathrm{Na}_{0.67} \mathrm{TmO}_{2}$ sample is $<0.67$ due to the $\mathrm{Na}^{+}$loss upon air-exposure, as shown in the following sections. XRD, NPD and ${ }^{23} \mathrm{Na}$ magic-angle-spinning nuclear magnetic resonance spectroscopy (MAS NMR, Supplementary Figs. 1-3 and Note 1) are three powerful techniques to identify the hydration impurities (birnessite) in $\mathrm{Na}_{\mathrm{x}} \mathrm{TmO}_{2}$ oxides, by characterizing the structural transitions, i.e. increased interlayer spacings. Fourier-transform infrared spectroscopy (FTIR) and ${ }^{23} \mathrm{Na}\left\{{ }^{1} \mathrm{H}\right\}$ rotational-echo double-resonance (REDOR) ${ }^{48}$ can be used to detect the existence of water molecules and protons in the $\mathrm{Na}_{\mathrm{x}} \mathrm{TmO}_{2}$ compounds, respectively (Supplementary Fig. 4 and Notes 1, and 2).

The structural transitions of the moisture-exposed P2$\mathrm{Na}_{\mathbf{0 . 6 7}} \mathrm{TmO}_{2}$. To investigate the structural changes of $\mathrm{P} 2-\mathrm{Na}_{\mathrm{x}} \mathrm{TmO}_{2}$ during the air-exposure, $\mathrm{Na}_{0.67} \mathrm{MnO}_{2}$ and $\mathrm{Na}_{0.67} \mathrm{Ni}_{0.33} \mathrm{Mn}_{0.67} \mathrm{O}_{2}$ were selected as model compounds for air-instable and air-stable electrodes, respectively ${ }^{27}$, to be exposed in different atmospheres of dry $\mathrm{CO}_{2}$, relative humidity $(\mathrm{RH}) 18 \%$ (without $\mathrm{CO}_{2}$ ), $\mathrm{RH}$ $15 \%+\mathrm{CO}_{2}$ (with presence of $\mathrm{CO}_{2}$ ), and $\mathrm{RH} 93 \%+\mathrm{CO}_{2}$ for 3 days ("Methods" part). As shown in the XRD patterns (Fig. 2a, b) and inductively coupled plasma-atomic emission spectrometry (ICPAES) results (Supplementary Table 2), the targeted materials were successfully prepared. It can be observed that all XRD peaks of $\mathrm{Na}_{0.67} \mathrm{MnO}_{2}$ remain unchanged when placed in the dry $\mathrm{CO}_{2}$ atmosphere (Fig. 2a), revealing that water is an inevitable component to destabilize $\mathrm{Na}_{0.67} \mathrm{TmO}_{2}$. At the atmospheres of $\mathrm{RH} 18 \%$ and $\mathrm{RH} 15 \%+\mathrm{CO}_{2}$, the hydration peaks (labeled with $\ddagger$ ) emerge and their intensities increase with the presence of $\mathrm{CO}_{2}$. With further increase in the relative humidity ( $\left.\mathrm{RH} 93 \%+\mathrm{CO}_{2}\right)$, all of the XRD peaks can be indexed to the hydration phase and $\mathrm{NaHCO}_{3}$ (labeled with $\nabla$ ), indicating that the $\mathrm{Na}_{0.67} \mathrm{MnO}_{2}$ is totally hydrated and partial $\mathrm{Na}^{+}$diffuses out from the sodium layers. For $\mathrm{Na}_{0.67} \mathrm{Ni}_{0.33} \mathrm{Mn}_{0.67} \mathrm{O}_{2}$, no obvious hydration peaks can be identified in all of the exposed samples (Fig. 2b), suggesting $\mathrm{Na}_{0.67} \mathrm{Ni}_{0.33} \mathrm{Mn}_{0.67} \mathrm{O}_{2}$ is more stable than $\mathrm{Na}_{0.67} \mathrm{MnO}_{2}$ in moist atmospheres. To quantify the hydration extent of the exposed samples, Rietveld refinements on the XRD patterns were conducted with a two-phase model and the results are shown in Fig. 2c. The mass ratios of hydrated phases in the exposed $\mathrm{Na}_{0.67} \mathrm{MnO}_{2}$ samples are $0 \%, 42 \%, 58 \%$, and $100 \%$ at the atmosphere of dry $\mathrm{CO}_{2}, \mathrm{RH}$ $18 \%$, $\mathrm{RH} 15 \%+\mathrm{CO}_{2}$, and $\mathrm{RH} 93 \%+\mathrm{CO}_{2}$, respectively, revealing that $\mathrm{P} 2-\mathrm{Na}_{\mathrm{x}} \mathrm{TmO}_{2}$ components are more vulnerable to $\mathrm{H}_{2} \mathrm{O}$ with both the existence of $\mathrm{CO}_{2}$ and the increment of relative humidity.

Figure $2 \mathrm{~d}-\mathrm{i}$ depicts the morphological change of $\mathrm{Na}_{0.67} \mathrm{MnO}_{2}$ and $\mathrm{Na}_{0.67} \mathrm{Ni}_{0.33} \mathrm{Mn}_{0.67} \mathrm{O}_{2}$ powder after the exposure to the atmosphere of $\mathrm{RH} 93 \%+\mathrm{CO}_{2}$ for 3 days. Scanning electron microscopy (SEM) images in Fig. 2d, g show that the surface of as-prepared $\mathrm{Na}_{0.67} \mathrm{MnO}_{2}$ and $\mathrm{Na}_{0.67} \mathrm{Ni}_{0.33} \mathrm{Mn}_{0.67} \mathrm{O}_{2}$ particles are clean and smooth. After exposure, severe delamination damages and a massive of intragranular cracks can be observed in hydrated
$\mathrm{Na}_{0.67} \mathrm{MnO}_{2}$ sample (Fig. 2e), as a result of the significant volume expansion of $\sim 30 \%$ during the hydration process. Besides structural changes, $\mathrm{NaHCO}_{3}$ particles are found on the surface of hydrated $\mathrm{Na}_{0.67} \mathrm{MnO}_{2}$, as shown in the energy dispersive X-ray spectroscopy (EDS) elemental mapping results (Fig. 2f). Moreover, the crystals with very regular morphologies can be observed in the exposed- $\mathrm{Na}_{0.67} \mathrm{MnO}_{2}$ powder (Supplementary Fig. 5a, b), which should be unambiguously identified to $\mathrm{NaHCO}_{3}$, according to the FTIR (Supplementary Fig. 4a) and EDS mapping results in Supplementary Fig. 5c. The formation of sodium salt is also observed in the air-exposed electrodes. As shown in Supplementary Fig. 6, sodium bicarbonate particles with nanoflakes morphology appear at the surface of the active materials. For exposed- $\mathrm{Na}_{0.67} \mathrm{Ni}_{0.33} \mathrm{Mn}_{0.67} \mathrm{O}_{2}$ sample, as shown in Fig. $2 \mathrm{~h}$, a rough surface is formed and there is no evidence of crack and layer glide, indicating that the morphological change of $\mathrm{Na}_{0.67} \mathrm{Ni}_{0.33} \mathrm{Mn}_{0.67} \mathrm{O}_{2}$ during exposure is more moderate than the $\mathrm{Na}_{0.67} \mathrm{MnO}_{2}$ sample (Fig. 2e). However, the EDS mapping results in Fig. $2 \mathrm{i}$ reveal that the $\mathrm{NaHCO}_{3}$ particles are formed on the surface of exposed $\mathrm{Na}_{0.67} \mathrm{Ni}_{0.33} \mathrm{Mn}_{0.67} \mathrm{O}_{2}$, indicating the $\mathrm{Na}^{+}$ loss in $\mathrm{Na}_{0.67} \mathrm{Ni}_{0.33} \mathrm{Mn}_{0.67} \mathrm{O}_{2}$ compound during exposure. In summary, the above XRD, SEM and EDS results indicate that $\mathrm{Na}_{0.67} \mathrm{MnO}_{2}$ samples experience chemical transitions upon airexposure, and $\mathrm{Na}_{0.67} \mathrm{Ni}_{0.33} \mathrm{Mn}_{0.67} \mathrm{O}_{2}$ changes as well.

Several influential factors especially relative humidity must be taken into consideration during the air-exposure experiments, soaking the samples in water is therefore a widely accepted testing procedure for confirming the stability of layered $\mathrm{Na}_{\mathrm{x}} \mathrm{TmO}_{2}$ oxides ${ }^{31}$. Moreover, water-stability is an important metric of $\mathrm{Na}_{\mathrm{x}} \mathrm{TmO}_{2}$ when applied as aqueous battery electrodes. Therefore, the structural evolutions of $\mathrm{Na}_{0.67} \mathrm{MnO}_{2}$ and $\mathrm{Na}_{0.67} \mathrm{Ni}_{0.33} \mathrm{Mn}_{0.67} \mathrm{O}_{2}$ samples in water have also been investigated. The results in Supplementary Figs. 7 and 8 and detailed analysis in Supplementary Note 3 suggest that the structural transformation mechanisms of $\mathrm{P} 2-\mathrm{Na}_{\mathrm{x}} \mathrm{TmO}_{2}$ in water are similar to that in moist air.

The role of $\mathrm{CO}_{2}$. The presence of $\mathrm{CO}_{2}$ makes a big difference in the structural transformations of $\mathrm{P} 2-\mathrm{Na}_{\mathrm{x}} \mathrm{TmO}_{2}$ upon moistureexposure (Fig. 2c). To characterize the functionality of $\mathrm{CO}_{2}$, we applied the TOF-SIMS to ascertain whether $\mathrm{CO}_{2}$ intercalates into the bulk of the $\mathrm{P} 2-\mathrm{Na}_{\mathrm{x}} \mathrm{TmO}_{2}$ during hydration ${ }^{5,26-28,30}$. In order to eliminate the influence of the surficial sodium bicarbonate species (Fig. 2f and Supplementary Fig. 4), we adopted a scavenging process (see details in the Methods section). The FTIR spectra in Fig. 3a reveal that $\mathrm{NaHCO}_{3}$ in the hydrated $\mathrm{Na}_{0.67} \mathrm{MnO}_{2}$ sample is successfully removed. TOF-SIMS depth profiles acquired on the scavenged powder show that the $\mathrm{H}_{2} \mathrm{O}$ $\left(\mathrm{OH}^{-}\right)$and $\mathrm{Mn}$ ions $\left(\mathrm{MnO}^{-}\right.$and $\left.\mathrm{MnO}_{2}^{-}\right)$appear at both surface and bulk of the powder (Fig. 3b), in good agreement with our refinement results (Supplementary Table 1). The signal intensity of $\mathrm{C}_{2} \mathrm{HO}^{-}$in the bulk ( 165 a.u., Supplementary Fig. 9 and Note 4 ) is only $2.5 \%$ compared to that of the prevailed $\mathrm{OH}^{-}$ (65k a.u.). Considering that the water content in hydrated $\mathrm{Na}_{0.67} \mathrm{MnO}_{2}$ is $\sim 0.45 \mathrm{~mol}$ per chemical formula unit (Supplementary Table 1), it is therefore reasonable to conclude that the $\mathrm{C}$ atoms in the bulk of the hydrated samples are negligible. Furthermore, the cross-sectional TOF-SIMS chemical mapping images of the tested secondary particles (Fig. 3c) show that the intensity of C-related species (e.g. $\mathrm{C}_{2} \mathrm{HO}^{-}, \mathrm{NaC}_{2} \mathrm{O}_{2}{ }^{-}, \mathrm{C}^{-}$) is much lower than $\mathrm{OH}^{-}$and $\mathrm{Mn}$-based ions and the remaining carbonate trace is mainly distributed on the surface rather than the bulk of the particles. This fact coincides well with the depth profile results in Fig. $3 \mathrm{~b}$ and Supplementary Fig. 9. Therefore, the function of $\mathrm{CO}_{2}$ is to increase the acidity at the particle's surface 

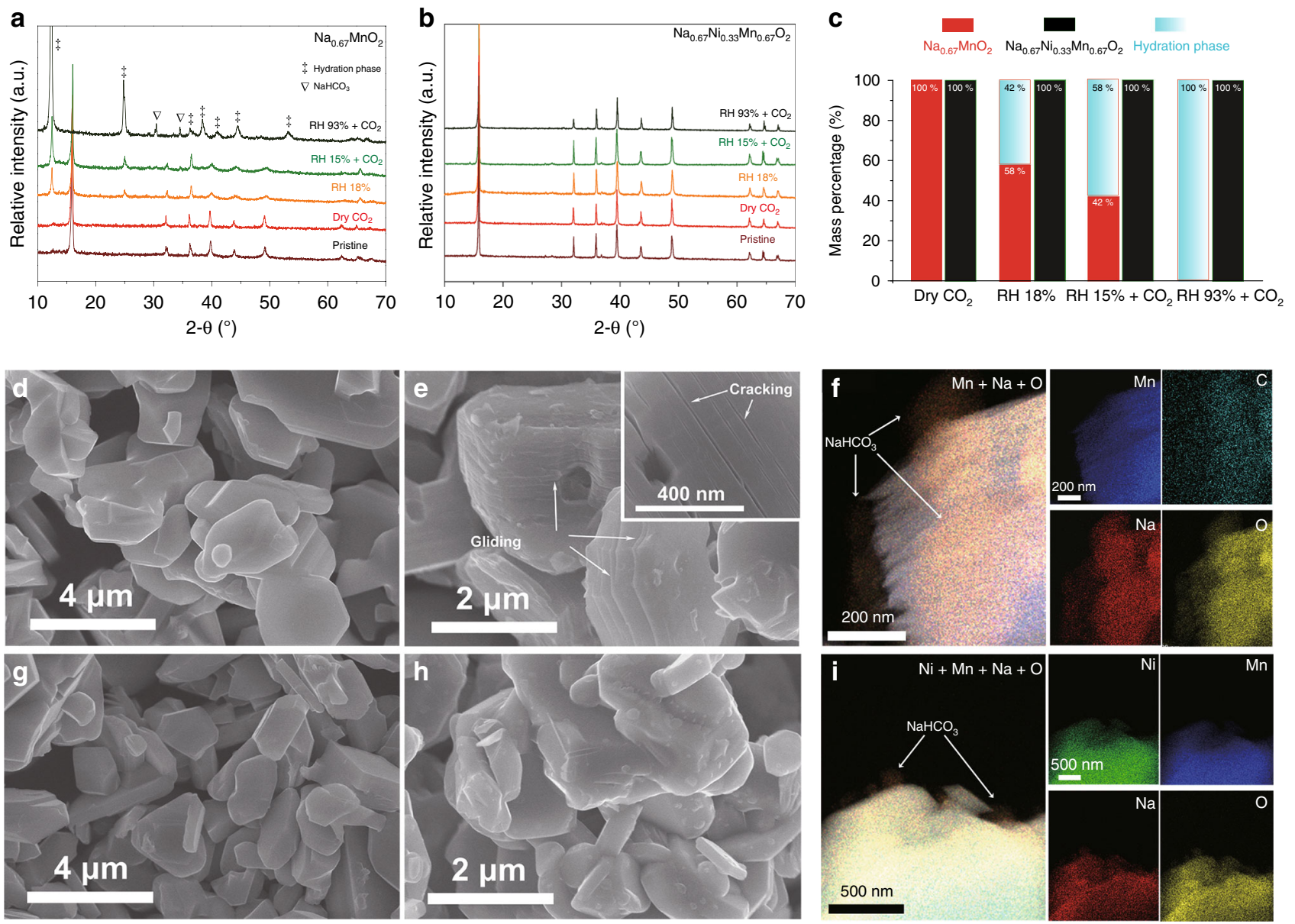

Fig. 2 The structural transitions of $\mathbf{P 2}-\mathbf{N a}_{\mathbf{0 . 6 7}} \mathbf{T m \mathbf { m } _ { 2 }}$ upon air-exposure. The XRD patterns of a $\mathrm{Na}_{0.67} \mathrm{MnO}_{2}$ and $\mathbf{b} \mathrm{Na}_{0.67} \mathrm{Ni}_{0.33} \mathrm{Mn}_{0.67} \mathrm{O}_{2}$ samples exposed in different atmosphere. $\mathbf{c}$ The refinement results of exposed $\mathrm{Na}_{0.67} \mathrm{MnO}_{2}$ and $\mathrm{Na}_{0.67} \mathrm{Ni}_{0.33} \mathrm{Mn}_{0.67} \mathrm{O}_{2}$ samples with a two-phase model. The $\mathrm{SEM}$ images of d pristine and e $\mathrm{RH} 93 \%+\mathrm{CO}_{2}$ exposed $\mathrm{Na}_{0.67} \mathrm{MnO}_{2}$ powder, $\mathbf{f}$ The EDS mapping results of exposed $\mathrm{Na}_{0.67} \mathrm{MnO}_{2}$, indicating that $\mathrm{NaHCO}_{3}$ is formed on the particles' surface. The SEM images of $\mathbf{g}$ pristine and $\mathbf{h} \mathrm{RH} 93 \%+\mathrm{CO}_{2}$ exposed $\mathrm{Na}_{0.67} \mathrm{Ni}_{0.33} \mathrm{Mn}_{0.67} \mathrm{O}_{2}$ powder. $\mathbf{i}$ The EDS mapping results of RH $93 \%+$ $\mathrm{CO}_{2}$ exposed $\mathrm{Na}_{0.67} \mathrm{Ni}_{0.33} \mathrm{Mn}_{0.67} \mathrm{O}_{2}$ samples, $\mathrm{NaHCO}_{3}$ particles are also observed on the surface of exposed $\mathrm{Na}_{0.67} \mathrm{Ni}_{0.33} \mathrm{Mn}_{0.67} \mathrm{O}_{2}$. The exposure time of the above samples are 3 days.

and accelerate the $\mathrm{Na}^{+}$loss rather than insert into the bulk of the $\mathrm{Na}_{\mathrm{x}} \mathrm{TmO}_{2}$ phases.

The critical sodium contents $\left(\boldsymbol{n}_{\boldsymbol{c}}\right)$ for hydration. Although $\mathrm{Na}_{0.67} \mathrm{Ni}_{0.33} \mathrm{Mn}_{0.67} \mathrm{O}_{2}$ has been reported to be one of the most air-stable $\mathrm{P} 2-\mathrm{Na}_{\mathrm{x}} \mathrm{TmO}_{2}$ oxides, the chemical change is observed in the EDS mapping as demonstrated in Fig. 2i. Furthermore, as shown in Fig. 4a, with longer exposure time, the intensity of the $\mathrm{NaHCO}_{3}$ diffraction peaks increases while the (002) diffraction peak shifts to lower 2-theta (Supplementary Fig. 10), suggesting the gradual extraction of $\mathrm{Na}^{+}$ from $\mathrm{Na}_{0.67} \mathrm{Ni}_{0.33} \mathrm{Mn}_{0.67} \mathrm{O}_{2}$ during exposure. To validate the identification of $\mathrm{NaHCO}_{3}$, the pristine and exposed $\mathrm{Na}_{0.67} \mathrm{Ni}_{0.33} \mathrm{Mn}_{0.67} \mathrm{O}_{2}$ samples are further scrutinized by FTIR. As shown in Supplementary Fig. 11, the characteristic peaks located at $600-2000 \mathrm{~cm}^{-1}$ in the FTIR spectrum of the exposed $\mathrm{Na}_{0.67} \mathrm{Ni}_{0.33} \mathrm{Mn}_{0.67} \mathrm{O}_{2}$ in $\mathrm{RH} 93 \%+\mathrm{CO}_{2}$ fit well with that of $\mathrm{NaHCO}_{3}$. The absence of the $\mathrm{O}-\mathrm{H}$ stretching signal between $\sim 2500$ and $3500 \mathrm{~cm}^{-1}$ suggests that no $\mathrm{H}_{2} \mathrm{O}$ intercalates into the sodium layers of $\mathrm{Na}_{0.67} \mathrm{Ni}_{0.33} \mathrm{Mn}_{0.67} \mathrm{O}_{2}$, which is highly consistent with the XRD results. In addition, as shown in Fig. $4 \mathrm{~b}$ and Supplementary Fig. 12 , the ${ }^{23} \mathrm{Na}$ MAS NMR signal of $\mathrm{Na}_{0.67} \mathrm{Ni}_{0.33} \mathrm{Mn}_{0.67} \mathrm{O}_{2}$ shifts to the upper field by $47 \mathrm{ppm}$, corresponding to the expansion of $\mathrm{c}$ parameter (Supplementary
Fig. 10). It is worth noting that the intensity of ${ }^{23} \mathrm{Na}\left\{{ }^{1} \mathrm{H}\right\}$ REDOR signal for the exposed $\mathrm{Na}_{0.67} \mathrm{Ni}_{0.33} \mathrm{Mn}_{0.67} \mathrm{O}_{2}$ sample decreases with ${ }^{1} \mathrm{H}$ irradiation as a function of the spin-echo time, as compared to that without ${ }^{1} \mathrm{H}$ irradiation. This result confirms that $\mathrm{H}^{+}$ions are in close proximity to the sodium atoms in the structure of the exposed $\mathrm{Na}_{0.67} \mathrm{Ni}_{0.33} \mathrm{Mn}_{0.67} \mathrm{O}_{2}$ sample. Thus, it is more likely that the $\mathrm{H}$ ions replace those lost $\mathrm{Na}^{+}$, indicative of the $\mathrm{Na}^{+} / \mathrm{H}^{+}$exchange mechanism. Moreover, given that the exposed electrodes usually exhibit improved open circuit potential ${ }^{26}$, another charge compensation mechanism, i.e. the oxidation of transition metal ions by $\mathrm{O}_{2}$ has been also proposed ${ }^{5}$. To validate which mechanism dominates the $\mathrm{Na}^{+}$loss process, X-ray absorption spectroscopy (XAS) was carried out. According to the previous results $8,20,49$, during the first charge process of $\mathrm{Na}_{0.67} \mathrm{Ni}_{0.33} \mathrm{Mn}_{0.67} \mathrm{O}_{2}$ electrode within $2.0-4.4 \mathrm{~V}$ (vs. $\mathrm{Na}^{+} / \mathrm{Na}$ ), $\mathrm{Mn}^{4+}$ ions remain stable and the oxidation/reduction of $\mathrm{Ni}$ ions compensates the electrochemical extraction/insertion of $\mathrm{Na}^{+}$. As shown in Supplementary Fig. 13a, both position and shape of the Ni K-edge remain unchanged, indicating that the valence state of $\mathrm{Ni}$ ions in the exposed $\mathrm{Na}_{0.67} \mathrm{Ni}_{0.33} \mathrm{Mn}_{0.67} \mathrm{O}_{2}$ is nearly the same as in the pristine sample. The valence state of $\mathrm{Mn}$ ions in pristine and hydrated $\mathrm{Na}_{0.67} \mathrm{MnO}_{2}$ samples has been also investigated by XAS. The pre-edge peak and main edge of Mn K-edge XAS 

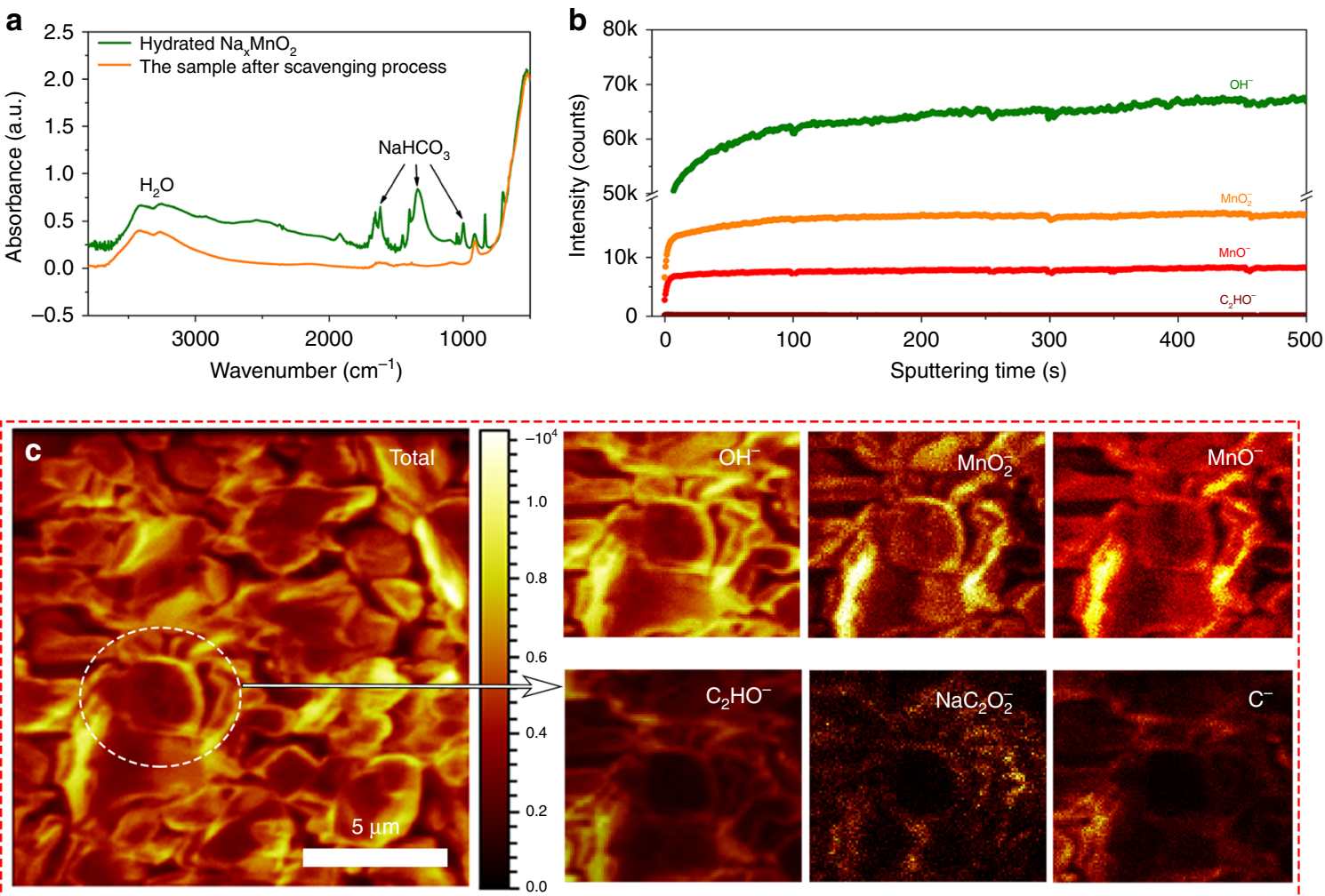

Fig. 3 TOF-SIMS results of the hydrated $\mathbf{N a}_{\mathbf{0 . 6 7}} \mathbf{M n O}_{\mathbf{2}}$ sample. a the comparison of FTIR spectra of the hydrated $\mathrm{Na}_{0.67} \mathrm{MnO}_{2}$ and hydrated $\mathrm{Na}_{0.67} \mathrm{MnO}_{2}$ after the scavenging process, indicating that after scavenging, most of the sodium (bi)carbonate impurities was removed. b TOP-SIMS spectra of OH ${ }^{-}$, $\mathrm{MnO}^{-}, \mathrm{MnO}_{2}^{-}$, and $\mathrm{C}_{2} \mathrm{HO}^{-}$secondary ion fragments over $500 \mathrm{~s} \mathrm{Cs}^{+}$sputtering along the depth profile of the sample after scavenging processes. c TOFSIMS chemical mapping of the hydrated $\mathrm{Na}_{0.67} \mathrm{MnO}_{2}$ after the scavenging process, showing the distribution of $\mathrm{OH}^{-}, \mathrm{MnO}_{2}^{-}, \mathrm{MnO}^{-}, \mathrm{C}_{2} \mathrm{HO}^{-}, \mathrm{NaC}_{2} \mathrm{O}_{2}^{-}$, and $\mathrm{C}^{-}$secondary ions.
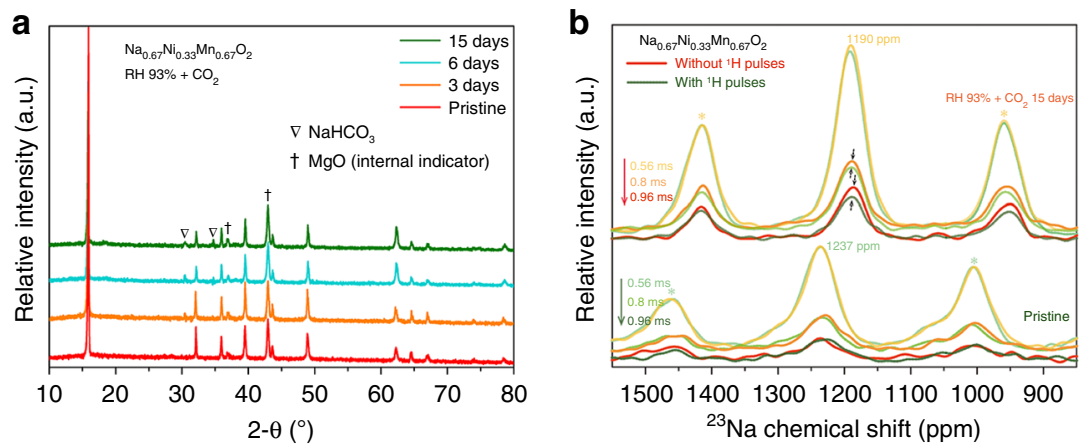

C
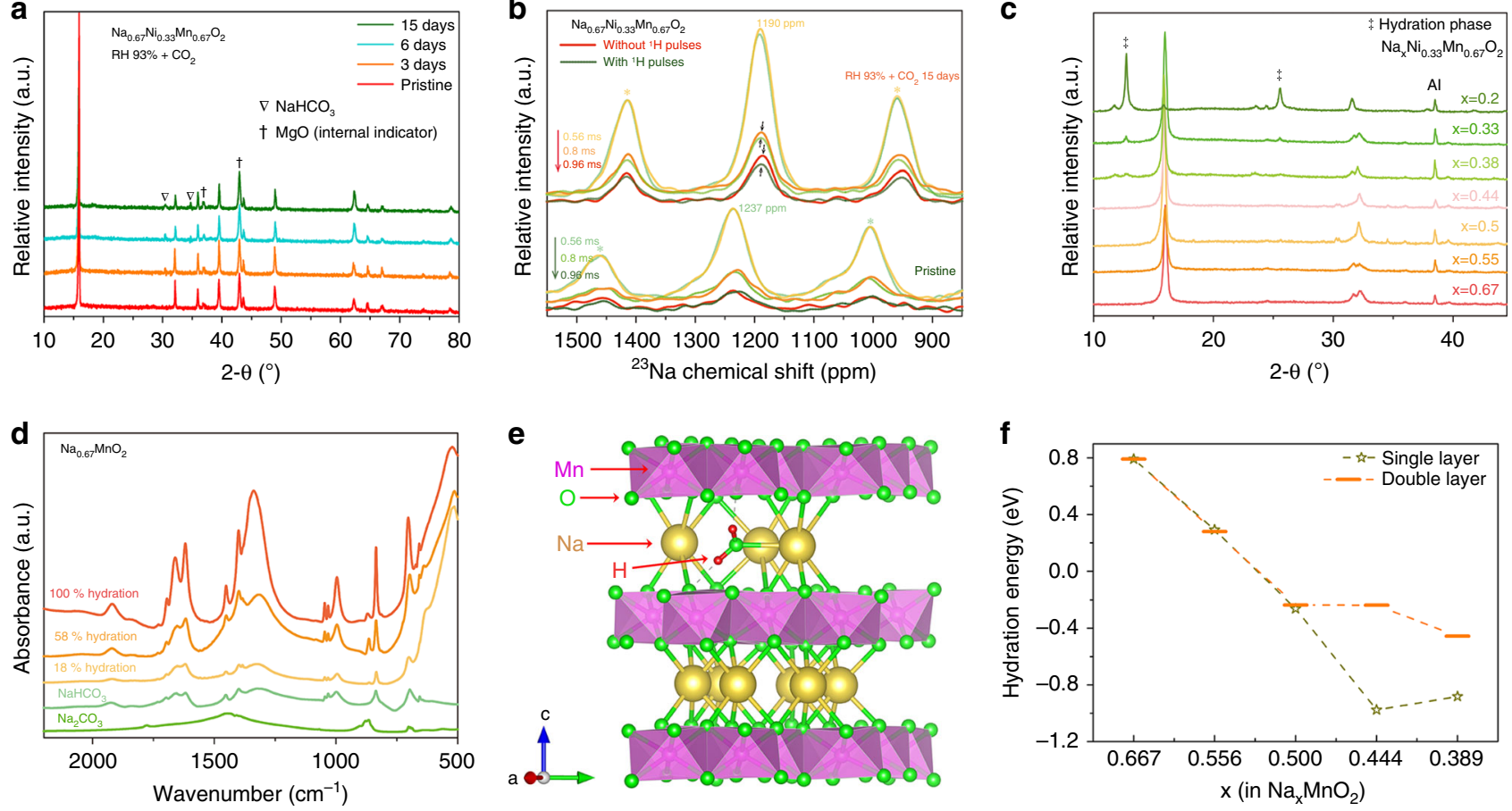

Fig. 4 The structural and chemical evolution mechanisms upon air-exposure. a The XRD evolutions of $\mathrm{Na}_{0.67} \mathrm{Ni}_{0.33} \mathrm{Mn}_{0.67} \mathrm{O}_{2}$ powder exposed at $\mathrm{RH} 93 \%$ $+\mathrm{CO}_{2}$ atmosphere for different times ( $\mathrm{MgO}$ was used as internal indicator). b ${ }^{23} \mathrm{Na}\left\{{ }^{1} \mathrm{H}\right\}$ REDOR-dephased ${ }^{23} \mathrm{Na}$ MAS NMR spectra (MAS rate: $25 \mathrm{kHz}$ ) and $\mathbf{c}$ The XRD patterns of exposed $\mathrm{Na}_{x} \mathrm{Ni}_{0.33} \mathrm{Mn}_{0.67} \mathrm{O}_{2}$ electrodes with various $\mathrm{Na}+$ content $x$. $\mathbf{d}$ The FTIR spectra of $\mathrm{Na}_{0.67} \mathrm{MnO}_{2}$ samples with various hydration degrees. e The structure model of single layer $\mathrm{Na}^{+}$loss structure for calculating hydration energies. $\mathbf{f}$ The calculated hydration energies for $\mathrm{Na}_{x} \mathrm{MnO}_{2}$ at various sodium contents $\mathrm{x}$. 
correspond to $1 s \rightarrow 3 d$ and $1 s \rightarrow 4 p$ transitions, respectively. However, the structural changes during hydration (Supplementary Fig. 13b) severely complicate the chemical shift of the main edge such that it becomes difficult to determine the valence state of $\mathrm{Mn}$ ions. Thus the pre-edge region could provide more reliable valent-state information ${ }^{50}$. As can be seen from Supplementary Fig. 13b, the splitting and intensity of pre-edge peaks of $\mathrm{Mn}$ ions are similar for all of the pristine, partially hydrated and totally hydrated samples, indicating that the changes of the valence state of $\mathrm{Mn}$ ions are negligible during hydration. The XAS results suggest that $\mathrm{Na}^{+} / \mathrm{H}^{+}$ exchange might be the main reaction that compensates for the extracted $\mathrm{Na}^{+}$in the moisture-exposed $\mathrm{Na}_{x} \mathrm{TmO}_{2}$. To confirm this conclusion, we stored the $\mathrm{Na}_{0.67} \mathrm{MnO}_{2}$ sample in three different atmospheres for 3 days, e.g. $\mathrm{O}_{2}$, $\mathrm{RH} 93 \%+\mathrm{CO}_{2}$ with the presence of $\mathrm{O}_{2}$, and $\mathrm{RH} 93 \%+\mathrm{CO}_{2}$ without $\mathrm{O}_{2}$. The XRD patterns in Fig. 2a and Supplementary Fig. $13 \mathrm{c}$ suggest that $\mathrm{O}_{2}$ makes smaller difference than both $\mathrm{CO}_{2}$ and water to the structural changes of $\mathrm{Na}_{\mathrm{x}} \mathrm{TmO}_{2}$.

To gain deeper insight into the structural/chemical transformation mechanisms of $\mathrm{P} 2-\mathrm{Na}_{\mathrm{x}} \mathrm{TmO}_{2}$ materials upon air-exposure, a series of $\mathrm{Na}_{\mathrm{x}} \mathrm{Ni}_{0.33} \mathrm{Mn}_{0.67} \mathrm{O}_{2}$ electrodes with different $\mathrm{Na}^{+}$contents were prepared by extracting $\mathrm{Na}^{+}$electrochemically, and then exposed at $\mathrm{RH} 93 \%+\mathrm{CO}_{2}$ atmosphere for 3 days. As shown in Fig. $4 c$, the hydration phase is absent at $\mathrm{Na}_{\mathrm{x}} \mathrm{Ni}_{0.33} \mathrm{Mn}_{2 / 3} \mathrm{O}_{2}$ electrodes within sodium contents of $0.67 \leq x \leq 0.44$. In $x=0.38$, the diffraction peaks of the hydration phase appear and its intensity increases with the further decrease of $\mathrm{Na}^{+}$contents. This result implies that hydration highly depend on the $\mathrm{Na}^{+}$contents. Specifically, if the sodium content $\boldsymbol{x}$ is lower than a critical sodium content $\boldsymbol{n}_{\boldsymbol{c}}$ (0.38-0.44 for $\mathrm{Na}_{\mathrm{x}} \mathrm{Ni}_{0.33} \mathrm{Mn}_{2 / 3} \mathrm{O}_{2}$ electrode), P2$\mathrm{Na}_{\mathrm{x}} \mathrm{TmO}_{2}$ materials are vulnerable for hydration and vice versa. The correlation between hydration degree and sodium contents $\boldsymbol{x}$ is also observed in $\mathrm{Na}_{\mathrm{x}} \mathrm{MnO}_{2}$ compounds. As representatively shown in Fig. 4 d, the intensity of $\mathrm{NaHCO}_{3}$ absorption peaks are positively associated with the hydration degrees of $\mathrm{Na}_{0.67} \mathrm{MnO}_{2}$ sample.

The density function theory (DFT) calculation was carried out to further understand the critical sodium content $\boldsymbol{n}_{\boldsymbol{c}}$. As shown in Fig. $4 \mathrm{e}$ and Supplementary Fig. 13d, two different sodium extraction models of single layer and double layer were considered, which correspond to the staging and random sodium extraction mechanisms, respectively ${ }^{15}$. The energy difference between $\mathrm{P} 2-\mathrm{Na}_{\mathrm{x}} \mathrm{TmO}_{2}$ with and without water molecules is defined as hydration energy. DFT calculation results in Fig. $4 \mathrm{f}$ show that when $x>0.52$, the hydration energy of $\mathrm{Na}_{\mathrm{x}} \mathrm{MnO}_{2}$ is higher than $0 \mathrm{eV}$, suggesting that water molecules cannot get inserted into the material. When the sodium content is lower than 0.52 , the hydration energy is lower than $0 \mathrm{eV}$, thus the hydrated structure is more stable than the un-hydrated structure. The foregoing energy analysis provides a chemical basis for understanding the sodium-content-dependent property in the hydration of $\mathrm{Na}_{\mathrm{x}} \mathrm{MnO}_{2}$ samples. Due to the low formation energy, the layered $\mathrm{Na}_{0.67} \mathrm{TmO}_{2}$ oxides will lose $\mathrm{Na}^{+}$spontaneously once in contact with moist air. When the sodium contents are lower than $\boldsymbol{n}_{\boldsymbol{c}}$, there is a strong repulsion between adjacent oxide layers $\left(\mathrm{TmO}_{2}\right)$ of $\mathrm{P} 2-\mathrm{Na}_{\mathrm{x}} \mathrm{TmO}_{2}$ oxides, and the insertion of $\mathrm{H}_{2} \mathrm{O}$ could lower the energy of $\mathrm{Na}_{0.67-\mathrm{x}-\mathrm{z}} \mathrm{H}_{\mathrm{x}} \mathrm{TmO}_{2}(\mathrm{x}$ and $\mathrm{z}$ correspond to the $\mathrm{Na}^{+}$loss that compensated by $\mathrm{Na}^{+} / \mathrm{H}^{+}$ exchange and $\mathrm{O}_{2}$ oxidation, respectively) due to the shielding effect of the water molecule and the expansion of sodium layer spacings. The above results also proved and interpreted the fact that hydration takes place after the extraction of $\mathrm{Na}^{+}$during airexposure.

Based on these results and analyses, the structural and chemical transformations of exposed $\mathrm{P} 2-\mathrm{Na}_{0.67} \mathrm{TmO}_{2}$ to different ambient atmospheres are summarized in Eqs. (1-4).
In the atmosphere without $\mathrm{CO}_{2}$ :

$x \cdot \mathrm{H}_{2} \mathrm{O}+\mathrm{Na}_{0.67} \mathrm{TmO}_{2}=\mathrm{Na}_{0.67-x} \mathrm{H}_{x} \mathrm{TmO}_{2}+x \cdot \mathrm{NaOH}$

In the atmosphere with scarce $\mathrm{CO}_{2}$ :

$$
\begin{aligned}
& x \cdot \mathrm{CO}_{2}+x \cdot \mathrm{H}_{2} \mathrm{O}+2 \cdot \mathrm{Na}_{0.67} \mathrm{TmO}_{2}=2 \cdot \mathrm{Na}_{0.67-x} \mathrm{H}_{x} \mathrm{TmO}_{2} \\
& +x \cdot \mathrm{Na}_{2} \mathrm{CO}_{3}
\end{aligned}
$$

In the atmosphere with abundant $\mathrm{CO}_{2}$ :

$$
\begin{aligned}
& x \cdot \mathrm{CO}_{2}+x \cdot \mathrm{H}_{2} \mathrm{O}+\mathrm{Na}_{0.67} \mathrm{TmO}_{2}=\mathrm{Na}_{0.67-x} \mathrm{H}_{x} \mathrm{TmO}_{2} \\
& +x \cdot \mathrm{NaHCO}_{3}
\end{aligned}
$$

If the sodium content in the electrode is lower than $\boldsymbol{n}_{\boldsymbol{c}}$ :

$$
\mathrm{Na}_{0.67-x} \mathrm{H}_{x} \mathrm{TmO}_{2}+y \cdot \mathrm{H}_{2} \mathrm{O}=\left[\mathrm{Na}_{0.67-x} \mathrm{H}_{x}\left(\mathrm{H}_{2} \mathrm{O}\right)_{y}\right] \mathrm{TmO}_{2}
$$

It should be emphasized that although Tm oxidation is not included in the proposed charge-compensation mechanisms due to lacking of direct spectroscopic evidences, there is still a high possibility that a minority of charge is compensated by the valence change of Tm ions. In the near future, more techniques, especially the state-of-the-art s-XAS characterizations are expected to obtain a deeper understanding of the charge-compensation mechanisms of $\mathrm{Na}^{+}$extraction in moisture-exposed $\mathrm{Na}_{\mathrm{x}} \mathrm{TmO}_{2}$.

The influence of structural changes on the electrochemical performances of $\mathbf{P 2}-\mathrm{Na}_{\mathbf{x}} \mathrm{TmO}_{2}$. In this section, we carefully investigate the influences of the above structural and chemical changes on the electrochemical performances of $\mathrm{Na}_{0.67} \mathrm{MnO}_{2}$ and $\mathrm{Na}_{0.67} \mathrm{Ni}_{0.33} \mathrm{Mn}_{2 / 3} \mathrm{O}_{2}$ electrodes. As shown in Fig. 5a, the pristine $\mathrm{Na}_{0.67} \mathrm{MnO}_{2}$ shows a high initial discharge capacity of $176 \mathrm{mAh} \mathrm{g}^{-1}$ at the current density of $12 \mathrm{~mA} \mathrm{~g}^{-1}$ within $2.0-4.4 \mathrm{~V}$. After 50 cycles, $66 \%$ of the initial capacity was retained, which coincides well with the previous results ${ }^{10,23}$. For the hydrated $\mathrm{Na}_{0.67} \mathrm{MnO}_{2}$ electrode, the reversible capacity is negligible at the initial cycles. In the $9^{\text {th }}$ cycle, although the discharge capacity increased to $\sim 150$ $\mathrm{mAh}^{-1}$, abnormal electrochemistry, such as long charging plateaus, large voltage hysteresis and low coulombic efficiency are also observed. These deviant electrochemical performances indicate that the large amount of $\mathrm{H}_{2} \mathrm{O}$ in the hydrated electrode has a pernicious influence on the organic-electrolyte based batteries.

The electrochemical performances of pristine $\mathrm{Na}_{0.67} \mathrm{Ni}_{0.33}$ $\mathrm{Mn}_{0.67} \mathrm{O}_{2}, \mathrm{Na}_{0.67} \mathrm{Ni}_{0.33} \mathrm{Mn}_{0.67} \mathrm{O}_{2}$ exposed in $\mathrm{RH} 93 \%+\mathrm{CO}_{2}$ for 3 days (denoted as exposed- $\mathrm{Na}_{0.67} \mathrm{Ni}_{0.33} \mathrm{Mn}_{0.67} \mathrm{O}_{2}$ ), and $\mathrm{Na}_{0.67}$ $\mathrm{Ni}_{0.33} \mathrm{Mn}_{0.67} \mathrm{O}_{2}$ immersed in water for 20 days (denoted as immersed- $\mathrm{Na}_{0.67} \mathrm{Ni}_{0.33} \mathrm{Mn}_{0.67} \mathrm{O}_{2}$ ) are presented in Fig. $5 \mathrm{c}-\mathrm{f}$. As shown in Fig. $5 c$, the pristine $\mathrm{Na}_{0.67} \mathrm{Ni}_{0.33} \mathrm{Mn}_{0.67} \mathrm{O}_{2}$, exposed$\mathrm{Na}_{0.67} \mathrm{Ni}_{0.33} \mathrm{Mn}_{0.67} \mathrm{O}_{2}$, and immersed- $\mathrm{Na}_{0.67} \mathrm{Ni}_{0.33} \mathrm{Mn}_{0.67} \mathrm{O}_{2}$ samples have very similar initial charge-discharge curves, suggesting that their structure and redox center are nearly identical ${ }^{8}$. However, the initial charge capacities of the exposed- $\mathrm{Na}_{0.67} \mathrm{Ni}_{0.33} \mathrm{Mn}_{0.67} \mathrm{O}_{2}\left(70 \mathrm{mAh} \mathrm{g}{ }^{-1}\right)$ and immersed- $\mathrm{Na}_{0.67} \mathrm{Ni}_{0.33} \mathrm{Mn}_{0.67} \mathrm{O}_{2}$ (77 $\left.\mathrm{mAh} \mathrm{g}^{-1}\right)$ are lower than that of the pristine $\mathrm{Na}_{0.67} \mathrm{Ni}_{0.33} \mathrm{Mn}_{0.67} \mathrm{O}_{2}$ (85 $\left.\mathrm{mAh} \mathrm{g} \mathrm{g}^{-1}\right)$, further confirming the loss of $\mathrm{Na}^{+}$ions during the exposure and immersing processes. Fig. $5 \mathrm{~d}$ compares the cycling stability of the three electrodes. It can be observed that the exposed- $\mathrm{Na}_{0.67} \mathrm{Ni}_{0.33} \mathrm{Mn}_{0.67} \mathrm{O}_{2}$ exhibits much lower coulombic efficiency than the pristine $\mathrm{Na}_{0.67} \mathrm{Ni}_{0.33} \mathrm{Mn}_{0.67} \mathrm{O}_{2}$, due to the influence of the sodium bicarbonate on the surface of exposed- $\mathrm{Na}_{0.67} \mathrm{Ni}_{0.33} \mathrm{Mn}_{0.67} \mathrm{O}_{2}$ particles. At the voltage range of $2.0-4.0 \mathrm{~V}$, the pristine $\mathrm{Na}_{0.67} \mathrm{Ni}_{0.33} \mathrm{Mn}_{0.67} \mathrm{O}_{2}$ material shows no evidence of capacity degradation after 100 cycles. In contrast, the immersed- $\mathrm{Na}_{0.67} \mathrm{Ni}_{0.33} \mathrm{Mn}_{0.67} \mathrm{O}_{2}$ and exposed$\mathrm{Na}_{0.67} \mathrm{Ni}_{0.33} \mathrm{Mn}_{0.67} \mathrm{O}_{2}$ samples decay fast in capacity, and retain low discharge capacity of 56 and $53 \mathrm{mAh} \mathrm{g}^{-1}$, corresponding to the capacity retention of $74 \%$ and $70 \%$, respectively. To get more insight 

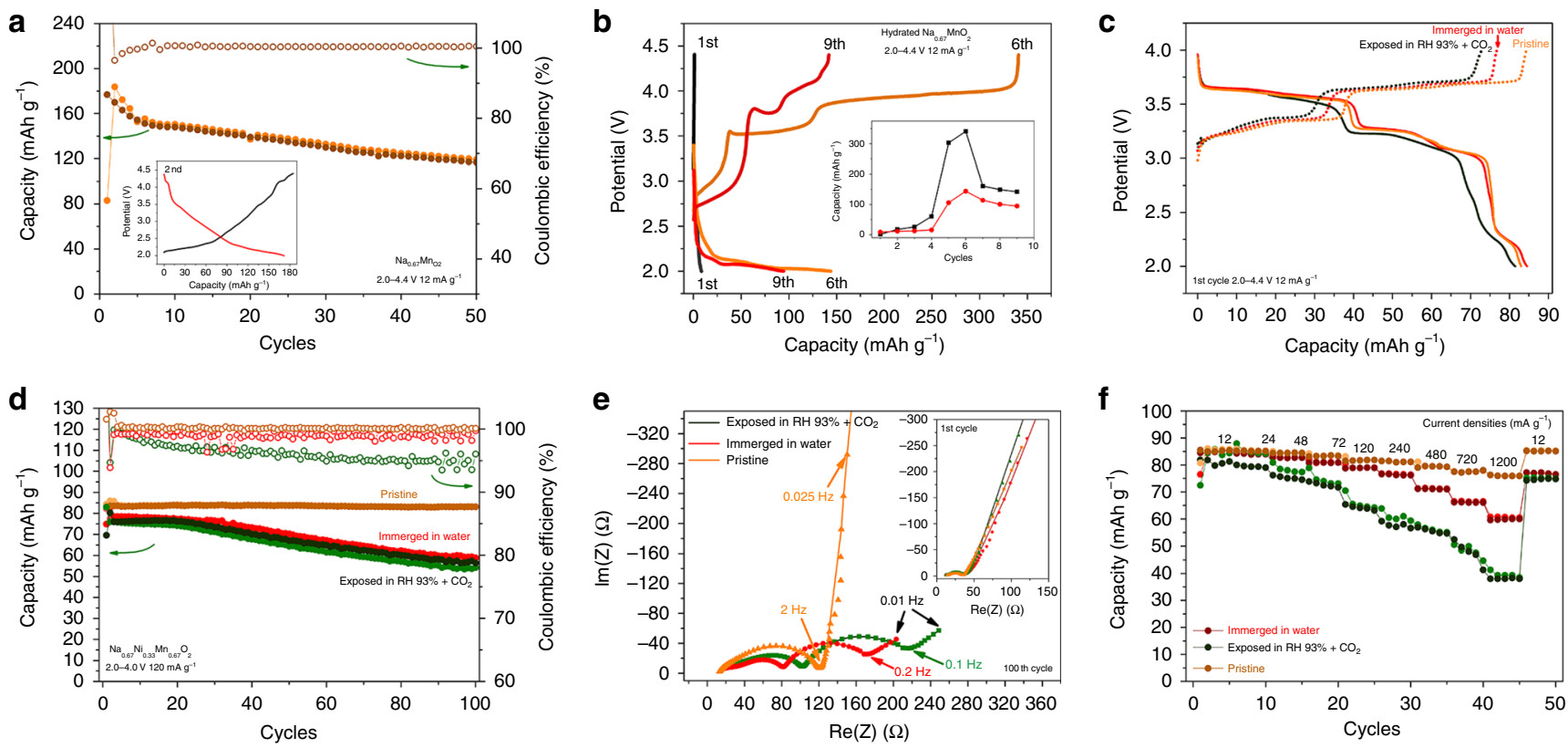

Fig. 5 Electrochemical performances of air-exposed $\mathbf{N a}_{\mathbf{0 . 6 7}} \mathbf{M n O}_{\mathbf{2}}$ and $\mathbf{N a}_{\mathbf{0 . 6 7}} \mathbf{N i}_{\mathbf{0 . 3 3}} \mathbf{M n}_{\mathbf{0 . 6 7}} \mathbf{O}_{\mathbf{2}}$. a The cycling performance of pristine $\mathrm{Na}_{0.67} \mathrm{MnO}_{2}$, the inset shows the charge-discharge curve at the 2 nd cycle. $\mathbf{b}$ The charge-discharge curves and cycling stability of totally hydrated $\mathrm{Na}_{0.67} \mathrm{MnO}_{2}$ sample. c-f The electrochemical performances within the voltage range of 2.0-4.0 V of three $\mathrm{Na}_{0.67} \mathrm{Ni}_{0.33} \mathrm{Mn}_{0.67} \mathrm{O}_{2}$ samples $\left(\right.$ pristine $\mathrm{Na}_{0.67} \mathrm{Ni}_{0.33} \mathrm{Mn}_{0.67} \mathrm{O}_{2}$, $\mathrm{Na}_{0.67} \mathrm{Ni}_{0.33} \mathrm{Mn}_{0.67} \mathrm{O}_{2}$ samples immersed in water for 20 days and exposed in $\mathrm{RH} 93 \%+\mathrm{CO}_{2}$ for 3 days). c The initial charge-discharge curves at $12 \mathrm{~mA} \mathrm{~g}^{-1}$. d The cycling stability of the three samples at $120 \mathrm{~mA} \mathrm{~g}^{-1}$ (after two formation cycles at $12 \mathrm{~mA} \mathrm{~g}^{-1}$ ). e The comparison of the impedance responses at the $1 \mathrm{st}$ and 100th cycles with frequency varied from $100 \mathrm{kHz}$ to $10 \mathrm{mHz}$. f The rate capability of three samples at the voltage range of $2.0-4.0 \mathrm{~V}$.

into the degradation mechanisms, the electrochemical impedance spectra (EIS) have been employed to study the resistance changes. The interface and charge-transfer resistances were estimated based on the equivalent circuit in Supplementary Fig. 14 and summarized in Supplementary Table 3. In the first cycle, the electrode resistance of the three samples is quite similar (the inset in Fig. 5e). After 100 cycles, the rapid increase of the surface resistance $\left(\mathrm{R}_{\mathrm{SEI}}\right)$ and charge transfer resistance $\left(\mathrm{R}_{\mathrm{C}, \mathrm{CT}}\right)$ for the exposed- $\mathrm{Na}_{0.67} \mathrm{Ni}_{0.33} \mathrm{Mn}_{0.67} \mathrm{O}_{2}$ and immersed- $\mathrm{Na}_{0.67} \mathrm{Ni}_{0.33} \mathrm{Mn}_{0.67} \mathrm{O}_{2}$ (Fig. 5e) samples indicates that the decomposition layer on the surface and the proton ions in the structure accelerate the depletion of the electrolyte thus blocking the diffusion of $\mathrm{Na}^{+}$ions. The comparison of rate capabilities shows a similar trend of cycling stability. As shown in Fig. 5f, the pristine $\mathrm{Na}_{0.67} \mathrm{Ni}_{0.33} \mathrm{Mn}_{0.67} \mathrm{O}_{2}$ electrode exhibits higher capacities than the immersed and exposed samples at all rates. The above electrochemical results demonstrate that exposure to moist air and immersion in water cause undesired structural changes and result in deteriorated electrochemical performances of $\mathrm{P} 2-\mathrm{Na}_{\mathrm{x}} \mathrm{TmO}_{2}$ samples.

The structural transformation of hydrated phases upon calcination in air. We have concluded that the sodium extraction (mainly compensated by $\mathrm{Na}^{+} / \mathrm{H}^{+}$exchange) and $\mathrm{H}_{2} \mathrm{O}$ insertion are two continuous structural transition processes during the exposure of $\mathrm{P} 2-\mathrm{Na}_{\mathrm{x}} \mathrm{TmO}_{2}$ samples, which usually impair their intrinsic electrochemical performances. The following questions need to be clarified: (i) whether or not these exposed samples can be recovered to their original structure and how, and (ii) what is the stoichiometry of hydrated phases (birnessite)? Therefore, in this section, the structural transitions of hydrated samples at the temperature range of $25-570{ }^{\circ} \mathrm{C}$ were investigated by in situ variable-temperature $\mathrm{XRD}$ technique. As shown in Fig. 6, five different stages can be observed in the in situ variabletemperature XRD pattern of the hydrated $\mathrm{Na}_{0.67} \mathrm{MnO}_{2}$. The mass loss at stage $a\left(25-130{ }^{\circ} \mathrm{C}\right)$ is $\sim 15.1 \%$, which includes decomposition of $\mathrm{NaHCO}_{3}{ }^{51}$ and extraction of water. At this stage, the hydration structure is well maintained. From stage $a$ to stage $b$, the hydrated phase is most probably transformed into a protonated phase (Supplementary Fig. 15 and Note 5) by twophase reaction mechanisms at $\sim 130^{\circ} \mathrm{C}$. The crystallinity of the $\mathrm{Na}_{0.67-\mathrm{x}-\mathrm{z}} \mathrm{MnO}_{2}$ phase at stage $c\left(217-297^{\circ} \mathrm{C}\right)$ is much lower than stage $b$, which might be resulted from the loss of protons. In addition, the sodium carbonate begins to decompose and results in the mass loss in stage $c$. With further increase in temperature, the crystallinity of $\mathrm{Na}_{0.67-\mathrm{x}-\mathrm{z}} \mathrm{MnO}_{2}$ increases, as shown in stage $d$. It should be pointed out that the decomposition temperature of $\mathrm{Na}_{2} \mathrm{CO}_{3}$ is lower than $800{ }^{\circ} \mathrm{C}$ due to the small sizes of the $\mathrm{Na}_{2} \mathrm{CO}_{3}$ particles (Fig. 2 and Supplementary Fig. 5) and the catalytic effect of transition metal oxides on reducing the energy requirement of $\mathrm{Na}_{2} \mathrm{CO}_{3}$ decomposition ${ }^{52}$. When the temperature is higher than $483^{\circ} \mathrm{C}$, the (100) and (103) peaks (at $\sim 35^{\circ}$ and $\sim 43^{\circ}$, respectively) of the $\mathrm{P} 2$ phase emerge gradually, indicating the $\mathrm{P} 2-\mathrm{Na}_{0.67} \mathrm{MnO}_{2}$ phase gradually recovers at stage $e$. However, the mass loss of $0.45 \%$ during $130-217^{\circ} \mathrm{C}$ corresponds to $x=0.61$ in $\mathrm{Na}_{0.67-\mathrm{x}-\mathrm{z}} \mathrm{H}_{\mathrm{x}} \mathrm{MnO}_{2}$, exceeding the amount of lost $\mathrm{Na}^{+}$ions $(x+$ $z \approx 0.39$, Supplementary Table 4 ), suggesting that the decomposition of $\mathrm{Na}_{2} \mathrm{CO}_{3}$ begins at stage $b\left(130-217^{\circ} \mathrm{C}\right)$. In conclusion, with the increase of temperature, the hydrated $\mathrm{Na}_{0.67} \mathrm{MnO}_{2}$ sample undergoes dehydration and $\mathrm{NaHCO}_{3}$ decomposition (70-130 $\left.{ }^{\circ} \mathrm{C}\right)$, deprotonation $\left(130-217^{\circ} \mathrm{C}\right), \mathrm{Na}_{2} \mathrm{CO}_{3}$ decomposition $\left(>130^{\circ} \mathrm{C}\right)$ and the recrystallization of $\mathrm{P} 2$ phase $\left(>483^{\circ} \mathrm{C}\right)$ process. In our recent work ${ }^{23}$, we demonstrate that $\mathrm{Na}_{0.67} \mathrm{Zn}_{0.1} \mathrm{Mn}_{0.67} \mathrm{O}_{2}$ is a promising $\mathrm{Na}$-ion battery cathode with outstanding cycling stability and better air-stability than $\mathrm{Na}_{0.67} \mathrm{MnO}_{2}$. Therefore, we also performed the in situ variabletemperature XRD of totally hydrated $\mathrm{Na}_{0.67} \mathrm{Zn}_{0.1} \mathrm{Mn}_{0.9} \mathrm{O}_{2}$ powder. Obviously, the structural transformation of the hydrated $\mathrm{Na}_{0.67} \mathrm{Zn}_{0.1} \mathrm{Mn}_{0.9} \mathrm{O}_{2}$ in Supplementary Fig. 16 is different from that of the hydrated $\mathrm{Na}_{0.67} \mathrm{MnO}_{2}$. From the hydration phase 


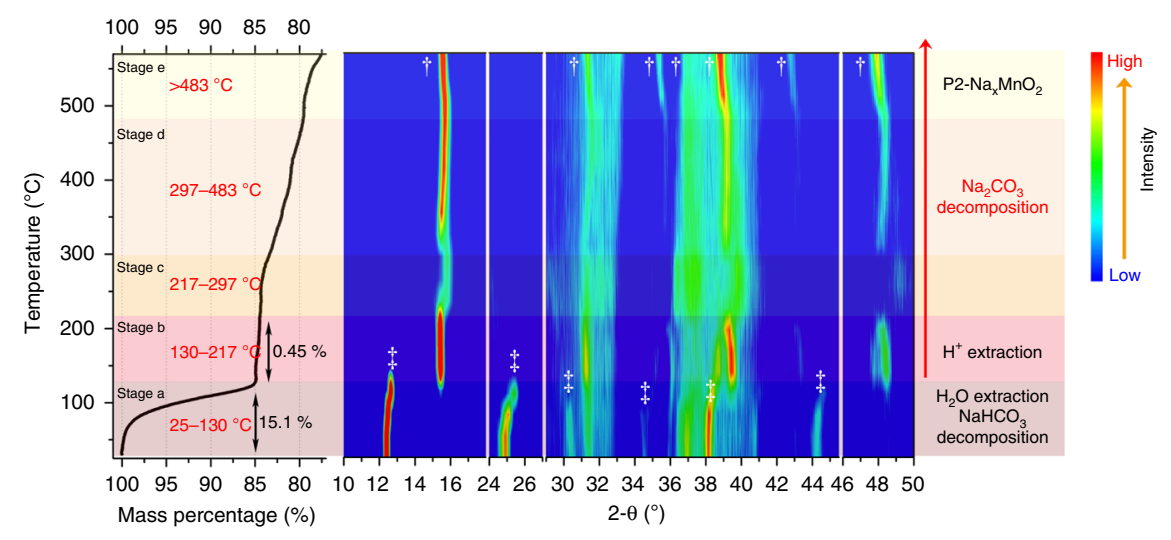

Fig. 6 Temperature-resolved in situ XRD of the totally hydrated $\mathbf{N a}_{\mathbf{0 . 6 7}} \mathbf{M n O}_{\mathbf{2}}$. The temperature ranges from 25 to $570{ }^{\circ} \mathrm{C}$. The TGA curves are shown at the left. Hydrated and P2 phases are labeled with " $\nmid$ " and " $\uparrow$ ", respectively.

(stage $a$ ) to the protonated phase (stage $b$ ), the combined mechanism of two-phase and solid-solution reactions can be recognized. Moreover, the temperature range of deprotonation of the hydrated $\mathrm{Na}_{0.67} \mathrm{Zn}_{0.1} \mathrm{Mn}_{0.9} \mathrm{O}_{2}$ sample is elusive and the temperature of the recrystallization of P2-type $\mathrm{Na}_{0.67} \mathrm{Zn}_{0.1}$ $\mathrm{Mn}_{0.9} \mathrm{O}_{2}$ phase $\left(376^{\circ} \mathrm{C}\right)$ is lower than that of $\mathrm{Na}_{0.67} \mathrm{MnO}_{2}$ $\left(483^{\circ} \mathrm{C}\right)$. The above results indicate that if the $\mathrm{Na}_{0.67} \mathrm{TmO}_{2}$ samples undergo sodium-loss and further hydration processes upon air-exposure, high-temperature annealing can be used to recover their original structures (the results of verification test are shown in Supplementary Fig. 17 and Note 6). Although the detailed structural transformation mechanisms during annealing are highly dependent on the stoichiometry of the exposed $\mathrm{Na}_{0.67} \mathrm{TmO}_{2}$, the general structural/chemical evolution processes are concluded in Eqs. (5-7) (Supplementary Note 7 and 8).

$30-130^{\circ} \mathrm{C}$ :

$$
\begin{gathered}
2 x \cdot \mathrm{NaHCO}_{3}=x \cdot \mathrm{Na}_{2} \mathrm{CO}_{3}+x \cdot \mathrm{H}_{2} \mathrm{O}+x \cdot \mathrm{CO}_{2} \\
{\left[\mathrm{Na}_{0.67-x} \mathrm{H}_{x}\left(\mathrm{H}_{2} \mathrm{O}\right)_{y}\right] \mathrm{TmO}_{2}=y \cdot \mathrm{H}_{2} \mathrm{O}+\left[\mathrm{Na}_{0.67-x} \mathrm{H}_{x}\right] \mathrm{TmO}_{2}}
\end{gathered}
$$

$$
130-900{ }^{\circ} \mathrm{C} \text { : }
$$

$$
\begin{aligned}
& 2 \cdot\left[\mathrm{Na}_{0.67-x} \mathrm{H}_{x}\right] \mathrm{TmO}_{2}+x \cdot \mathrm{Na}_{2} \mathrm{CO}_{3}= x \cdot \mathrm{H}_{2} \mathrm{O}+x \cdot \mathrm{CO}_{2} \\
&+2 \cdot \mathrm{Na}_{0.67} \mathrm{TmO}_{2}
\end{aligned}
$$

According to the structural/chemical evolution processes revealed by the above in situ XRD patterns, the chemical formulas of several hydrated $\mathrm{Na}_{0.67} \mathrm{TmO}_{2}$ materials, including $\mathrm{Na}_{0.67} \mathrm{MnO}_{2}$, $\mathrm{Na}_{0.67} \mathrm{Al}_{0.1} \mathrm{Mn}_{0.9} \mathrm{O}_{2}, \mathrm{Na}_{0.67} \mathrm{Cu}_{0.1} \mathrm{Mn}_{0.9} \mathrm{O}_{2}, \mathrm{Na}_{0.67} \mathrm{Zn}_{0.1} \mathrm{Mn}_{0.9} \mathrm{O}_{2}$, and $\mathrm{Na}_{0.67} \mathrm{Zn}_{0.2} \mathrm{Mn}_{0.8} \mathrm{O}_{2}$, are identified based on the TGA analysis (see detailed information in Supplementary Figs. 18 and 19, Table 4, Supplementary Eqs. (1-8), and Supplementary Note 8). ICP-AES analyses in Supplementary Table 4 are in good agreement with the chemical formulas of hydration phases. The results suggest that the contents of inserted $\mathrm{H}_{2} \mathrm{O}$ vary greatly from $\sim 0.1$ to 0.45 depending on the stoichiometry of pristine materials.

The comprehensive structural/chemical evolution mechanisms upon air-exposure. Based on our analysis above, we summarize the structural and chemical transitions of the $\mathrm{P} 2-\mathrm{Na}_{0.67} \mathrm{TmO}_{2}$ components upon air exposure in Fig. 7a. At the initial stage, because of the low formation energy of layered $\mathrm{Na}_{0.67} \mathrm{TmO}_{2}$ oxides, the sodium ions are lost from the bulk and form amorphous $\mathrm{Na}_{2} \mathrm{CO}_{3} / \mathrm{NaHCO}_{3}$ layer on the surface of particles or even $\mathrm{Na}_{2} \mathrm{CO}_{3} / \mathrm{NaHCO}_{3}$ crystals with charge-compensation mechanism of $\mathrm{Na}^{+} / \mathrm{H}^{+}$exchange. The formation energy increases with the extraction of $\mathrm{Na}^{+}$ions and finally the $\mathrm{P} 2-\mathrm{Na}_{\mathrm{x}} \mathrm{TmO}_{2}$ oxides are stable at the sodium content of $0.67-\mathrm{x}-\mathrm{z}$ in a specific environment. If the remaining sodium content $0.67-\mathrm{x}-\mathrm{z}$ is lower than the critical sodium content $\boldsymbol{n}_{\boldsymbol{c}}$, the water molecules go into the sodium layers and form the hydration phases. Considering the full decomposition of generated sodium salts and the recrystallization of the degraded structures, once the $\mathrm{Na}_{0.67} \mathrm{TmO}_{2}$ is protonated or hydrated, high-temperature calcination is needed to recover the hydrated forms back to the original structure. In addition to the above structural transitions, the outer layer of $\mathrm{Na}_{\mathrm{x}} \mathrm{TmO}_{2}$ particles decomposes into transition-metal oxides/hydroxides when exposed to air or immersed in water. As shown in Supplementary Fig. 20, after exposing $\mathrm{Na}_{0.67} \mathrm{Cu}_{0.33} \mathrm{Mn}_{0.67} \mathrm{O}_{2}$ at $\mathrm{RH} 93 \%+\mathrm{CO}_{2}$ for 6 days, the $\mathrm{Cu}_{2} \mathrm{O}$ and $\mathrm{NaHCO}_{3}$ impurities can be observed in the XRD pattern, indicating that degradation is more or less an inevitable process at the surface of exposed $\mathrm{Na}_{0.67} \mathrm{TmO}_{2}$ compounds. Manthiram's group also reported that the Ni-rich layered sodium oxide transforms into $\mathrm{NiO}$ and $\mathrm{Na}_{2} \mathrm{CO}_{3}$ in the surface ${ }^{26}$. In brief, the structural and chemical transitions coexist, rather than a single protonation/Tm-oxidation, hydration, and degradation mechanism.

Evaluating the air-stability of $\mathrm{Na}_{\mathbf{x}} \mathrm{TmO}_{2}$ electrodes. The choice and evaluation of air-stable $\mathrm{Na}_{\mathrm{x}} \mathrm{TmO}_{2}$ electrodes have attracted enormous attention. It has been widely accepted that the $\mathrm{Ni} / \mathrm{Mn}$ superlattice prevents the intercalation of $\mathrm{H}_{2} \mathrm{O}$ since $\mathrm{P} 2$ $\mathrm{Na}_{0.67} \mathrm{Ni}_{0.33} \mathrm{Mn}_{0.67} \mathrm{O}_{2}$ was found to be resistant to hydration in moisture ${ }^{27}$. However, our results demonstrate that $\mathrm{Na}_{0.67} \mathrm{Ni}_{0.33} \mathrm{Mn}_{0.67} \mathrm{O}_{2}$ is not as stable in moist air as it was expected, while other reported air-stable electrodes, such as $\mathrm{Na}_{0.78} \mathrm{Cu}_{0.27} \mathrm{Zn}_{0.06} \mathrm{Mn}_{0.67} \mathrm{O}_{2}{ }^{32}, \mathrm{Na}_{0.67} \mathrm{Ni}_{0.22} \mathrm{Cu}_{0.11} \mathrm{Ti}_{0.11} \mathrm{Mn}_{0.56} \mathrm{O}_{2}{ }^{35}$ and $\mathrm{Na}_{7 / 9} \mathrm{Cu}_{2 / 9} \mathrm{Fe}_{1 / 9} \mathrm{Mn}_{2 / 3} \mathrm{O}_{2}{ }^{53}$ do not have superlattice ordering in Tm layers. Therefore, the crucial factors, as well as the evaluation principles related to the air-stability of $\mathrm{Na}_{\mathrm{x}} \mathrm{TmO}_{2}$ electrodes, have yet to be re-explored.

Therefore, we compared the air-stability of five layered oxides with different $\mathrm{Mn}$ valence-state and redox potential, e.g. $\mathrm{Na}_{0.67} \mathrm{MnO}_{2}$, $\mathrm{Na}_{0.67} \mathrm{Al}_{0.1} \mathrm{Mn}_{0.9} \mathrm{O}_{2}, \quad \mathrm{Na}_{0.67} \mathrm{Zn}_{0.1} \mathrm{Mn}_{0.9} \mathrm{O}_{2}, \quad \mathrm{Na}_{0.67} \mathrm{Zn}_{0.2} \mathrm{Mn}_{0.8} \mathrm{O}_{2}$ and $\mathrm{Na}_{0.67} \mathrm{Ni}_{0.33} \mathrm{Mn}_{0.66} \mathrm{O}_{2}$, at the atmosphere of dry $\mathrm{CO}_{2}, \mathrm{RH} 18 \%$, $\mathrm{RH} 15 \%+\mathrm{CO}_{2}$, and $\mathrm{RH} 93 \%+\mathrm{CO}_{2}$. The XRD patterns and ICPAES results of these pristine oxides are presented in Supplementary Fig. 21 and Table 5, respectively. In addition, the XRD patterns and the corresponding quantification of the hydration extents of the exposed samples are shown in Supplementary Fig. 22. According to the refinement results in Supplementary Fig. 22e, it is confirmed once again that more structural and chemical changes of $\mathrm{Na}_{0.67} \mathrm{TmO}_{2}$ occur with the increase of relative humidity and the presence of $\mathrm{CO}_{2}$. Moreover, it can be clearly observed 
a

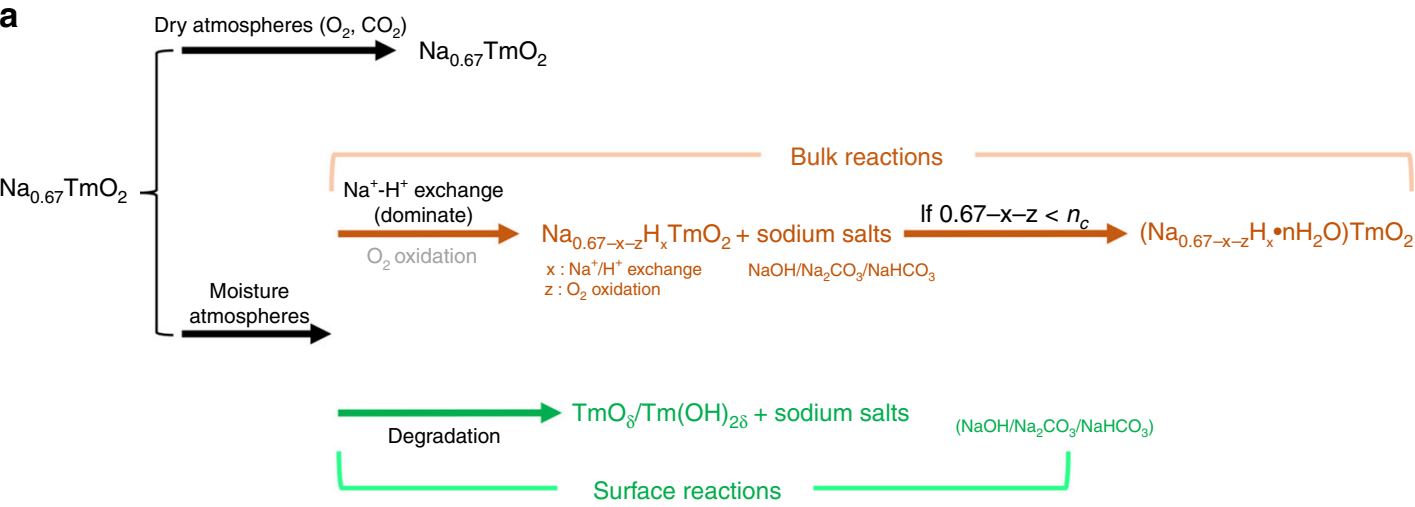

b

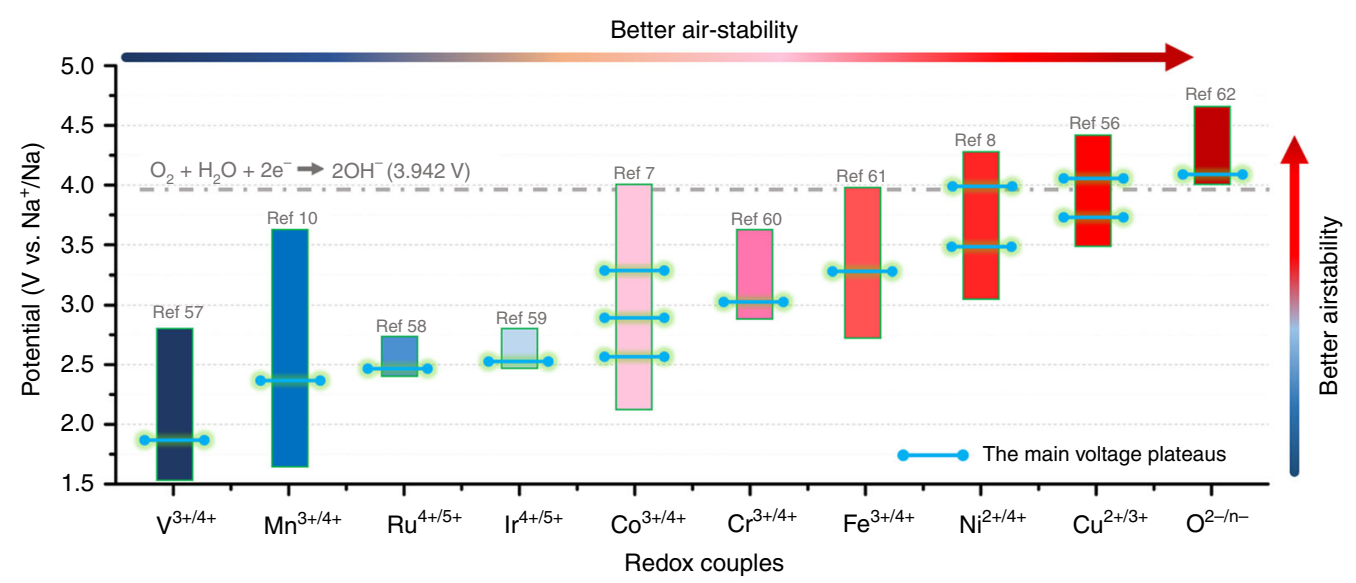

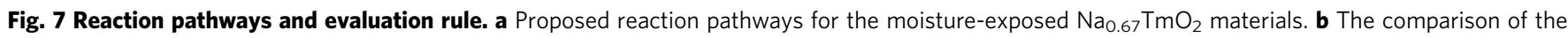
main redox couples in layered sodium transition metal oxides.

that the air-stability of these investigated layered oxides follows the order of $\mathrm{Na}_{0.67} \mathrm{Ni}^{2+}{ }_{0.33} \mathrm{Mn}^{4+}{ }_{0.67} \mathrm{O}_{2}>\mathrm{Na}_{0.67}$ $\mathrm{Zn}^{2+}{ }_{0.2} \mathrm{Mn}^{3.66+}{ }_{0.8} \mathrm{O}_{2}>\mathrm{Na}_{0.67} \mathrm{Zn}^{2+}{ }_{0.1} \mathrm{Mn}^{3.47+}{ }_{0.9} \mathrm{O}_{2}>\mathrm{Na}_{0.67}$ $\mathrm{Al}^{3+}{ }_{0.1} \mathrm{Mn}^{3.37}+{ }_{0.9} \mathrm{O}_{2}>\mathrm{Na}_{0.67} \mathrm{Mn}^{3.33}+\mathrm{O}_{2}$, suggesting that the air-stability is closely related to the valence state of $\mathrm{Mn}$ ions or the redox potential of the initial charge process (Supplementary Fig. 23). To confirm this hypothesis, several electrodes were prepared and exposed to the atmosphere of $\mathrm{RH} 93 \%+\mathrm{CO}_{2}$. As shown in Supplementary Fig. 24, although the valence state of $\mathrm{Mn}$ ions in $\mathrm{Na}_{0.67} \mathrm{Co}^{3+}{ }_{0.67} \mathrm{Mn}^{4+}{ }_{0.33} \mathrm{O}_{2}, \quad \mathrm{Na}_{0.67} \mathrm{Ni}^{2+}{ }_{0.17} \mathrm{Co}^{3+}{ }_{0.33}$ $\mathrm{Mn}^{4+}{ }_{0.50} \mathrm{O}_{2}$ and $\mathrm{Na}_{0.67} \mathrm{Ni}^{2+}{ }_{0.17} \mathrm{Fe}^{3+}{ }_{0.33} \mathrm{Mn}^{4+}{ }_{0.50} \mathrm{O}_{2}$ electrodes are $\mathrm{Mn}^{4+}$, all of these samples are hydrated after three days' exposure in the atmosphere of $\mathrm{RH} 93 \%+\mathrm{CO}_{2}$, indicating that the valence state of $\mathrm{Mn}$ ions is not the key parameter for the air-stability property. Therefore, $\mathrm{Na}_{0.67} \mathrm{Li}_{0.20} \mathrm{Mn}_{0.80} \mathrm{O}_{2}{ }^{54}, \quad \mathrm{Na}_{0.67} \mathrm{Mg}_{0.28}$ $\mathrm{Mn}_{0.72} \mathrm{O}_{2}{ }^{55}$ and $\mathrm{Na}_{0.67} \mathrm{Cu}_{0.33} \mathrm{Mn}_{0.67} \mathrm{O}_{2}{ }^{56}$ samples that have high initial charging potential were prepared and exposed to the same atmosphere. As shown in Supplementary Fig. 20 and 25, after the exposure for 3 or 6 days, no hydration peaks can be recognized, indicating that the $\mathrm{Na}_{0.67} \mathrm{TmO}_{2}$ components with higher redox potential in the first cycles exhibit better air-stability. Generally, for a $\mathrm{Na}_{0.67} \mathrm{TmO}_{2}$ material with higher electrochemical redox potential (equilibrium potential), it is more difficult to extract $\mathrm{Na}^{+}$ from the lattice chemically. Therefore, the potential of redox couples could be considered as one of the key principles to evaluate the air-stability of $\mathrm{Na}_{0.67} \mathrm{TmO}_{2}$ electrodes. Based on the above conclusion, we summarize the main redox couples in $\mathrm{P} 2-\mathrm{Na}_{\mathrm{x}} \mathrm{TmO}_{2}$ electrodes (Fig. $7 \mathrm{~b}$ ), including $\mathrm{V}^{3+/ 4+57}, \mathrm{Mn}^{3+/ 4+10}, \mathrm{Ru}^{4+/ 5+58}$, $\mathrm{Ir}^{4+/ 5+59}, \mathrm{Co}^{3+/ 4+7}, \mathrm{Cr}^{3+/ 4+60}, \mathrm{Fe}^{3+/ 4+61}, \mathrm{Ni}^{2+/ 4+8}, \mathrm{Cu}^{2+/ 3+56}$, and $\mathrm{O}^{2-/ \mathrm{n}-62}$. The result suggests that the electrodes with redox couples of $\mathrm{Ni}^{2+/ 4+}, \mathrm{Cu}^{2+/ 3+}$, and $\mathrm{O}^{2-/ \mathrm{n}-}$ show much better air-stability than that with the redox couples of $\mathrm{V}^{3+/ 4+}, \mathrm{Mn}^{3+/ 4+}$, $\mathrm{Co}^{3+/ 4+}, \mathrm{Fe}^{3+/ 4+}$, etc., which is in good agreement with the previous articles $5,32,34,35,63$.

Besides chemical compositions, the crystallinity of $\mathrm{Na}_{0.67} \mathrm{TmO}_{2}$ also makes a great difference to their air-stability. Supplementary Fig. 26a,b show the weight loss and XRD evolutions during the preparation process of $\mathrm{Na}_{0.67} \mathrm{MnO}_{2}$, respectively. When the temperature increases to $480^{\circ} \mathrm{C}, \mathrm{Na}_{2} \mathrm{CO}_{3}$ begins to decompose and the $\beta-\mathrm{MnO}_{2}$ (JCPDF: 72-1984) starts to transform into the layered $\mathrm{Na}_{0.67} \mathrm{MnO}_{2}$. The XRD peaks of $\beta-\mathrm{MnO}_{2}$ disappear at $\sim 540{ }^{\circ} \mathrm{C}$ and all of the $\mathrm{Na}_{2} \mathrm{CO}_{3}$ is decomposed at $\sim 640^{\circ} \mathrm{C}$. We compared the air-stability of the $\mathrm{Na}_{0.67} \mathrm{MnO}_{2}$ samples at $640{ }^{\circ} \mathrm{C}$, $900^{\circ} \mathrm{C}$, and the sample calcinated at $900^{\circ} \mathrm{C}$ for $900 \mathrm{~min}$, which exhibit increased crystallinity (Supplementary Fig. 26b). As shown in Supplementary Fig. 26c, after being exposed in $\mathrm{RH}$ $18 \%$ atmosphere for 3 days, the hydration degree follows the order of $640{ }^{\circ} \mathrm{C}>900{ }^{\circ} \mathrm{C}>900{ }^{\circ} \mathrm{C} 900 \mathrm{~min}$ samples, and clearly indicates that the samples with higher degree of crystallinity exhibit better air-stability.

\section{Discussion}

In summary, a comprehensive investigation of the structural and chemical transformations of $\mathrm{P} 2-\mathrm{Na}_{\mathrm{x}} \mathrm{TmO}_{2}$ in different ambient atmospheres has been carried out. Using advanced technique characterizations and systematic investigation, we clarified and rationalized these intertwined reaction processes and their determining factors. For example, the critical roles of relative humidity and $\mathrm{CO}_{2}$ in the air-stability of $\mathrm{P} 2-\mathrm{Na}_{0.67} \mathrm{TmO}_{2}$, the extraction of $\mathrm{Na}^{+}$ions from $\mathrm{Na}_{0.67} \mathrm{Ni}_{0.33} \mathrm{Mn}_{0.67} \mathrm{O}_{2}$ when exposed to moist air or emerged in water, the influence of 
moisture-exposure on the electrochemical performances of $\mathrm{Na}_{\mathrm{x}} \mathrm{TmO}_{2}$, the precise quantification of water contents in hydrated phases, and the significance of crystallinity on the airstability of $\mathrm{Na}_{\mathrm{x}} \mathrm{TmO}_{2}$, etc. Furthermore, based on the detailed mechanisms, including the $\mathrm{Na}$ extraction at the initial stage of moisture-exposure, the dominate $\mathrm{Na}^{+} / \mathrm{H}^{+}$exchange chargecompensation mechanism, and the critical sodium content $\left(n_{c}\right)$, we proposed a general and in-depth picture on the chemical/ structural evolutions of $\mathrm{P} 2-\mathrm{Na}_{\mathrm{x}} \mathrm{TmO}_{2}$ during moisture-exposure. In addition, by extending the study to a variety of layered sodium-based oxides $\left(\mathrm{Na}_{0.67} \mathrm{M}_{\mathrm{x}} \mathrm{Mn}_{1-\mathrm{x}} \mathrm{O}_{2}\right.$, with $\mathrm{M}=\mathrm{Ni}, \mathrm{Zn}, \mathrm{Fe}, \mathrm{Al}$, $\mathrm{Co}, \mathrm{Li}, \mathrm{Mg}, \mathrm{Cu}$, etc.) we have also demonstrated that the redox potential properties in the first charge process could be used as an empirical rule for evaluating the air-stability of $\mathrm{Na}_{\mathrm{x}} \mathrm{TmO}_{2}$ electrodes. Our results provide significant new clues for the design, synthesis, storage, and application of layered sodium cathodes, as well as other alkali-metal transition metal oxides.

\section{Methods}

Preparation of layered materials. The pristine $\mathrm{Na}_{\mathrm{x}} \mathrm{TmO}_{2}$ cathodes have been synthesized by high-temperature solid-state reactions ${ }^{12,23}$. Stoichiometric amounts of raw materials, e.g. $\mathrm{MnO}_{2}$ (99.95\%, Aladdin), $\mathrm{ZnO}$ (99.99\%, Aladdin), $\mathrm{NiO}$ (99.99\%, Aladdin), $\mathrm{Al}_{2} \mathrm{O}_{3}$ (99.99\%, Aladdin), $\mathrm{TiO}_{2}$ (99.8\%, Aladdin), $\mathrm{CuO}$ (99.9\%, Aladdin), $\mathrm{Li}_{2} \mathrm{CO}_{3}$ (99.99\%, Aladdin), and $\mathrm{Na}_{2} \mathrm{CO}_{3}$ (99.99\%, Aladdin) were ball-milled with acetone solvent for $3.5 \mathrm{~h}$ at $500 \mathrm{rpm}$. Then dried at $120^{\circ} \mathrm{C}$ overnight, pressed into pellets and heated at $900^{\circ} \mathrm{C}$ for $15 \mathrm{~h}$ in air. After slowly cooled to $150^{\circ} \mathrm{C}$ in the furnace, the pellets were transferred to an Ar-filled glove box immediately, ground and kept the final products in the Ar-filled glove box.

Hydration tests. The saturated salt solutions could produce stable relative humidity in a closed system at a certain temperature ${ }^{64,65}$. To study the effect of different ambient atmospheres on the structural and chemical stability of $\mathrm{Na}_{\mathrm{x}} \mathrm{TmO}_{2}$, the prepared $\mathrm{Na}_{0.67} \mathrm{TmO}_{2}$ oxides are put in a centrifuge tube and then aged on an airtight container under four different storage conditions at the constant temperature of $40{ }^{\circ} \mathrm{C}$. They are dry $\mathrm{CO}_{2}$, controlled humidity of $\mathrm{RH} 18 \%$ (without $\mathrm{CO}_{2}$ ), $\mathrm{RH} 15 \%$ with $\mathrm{CO}_{2}$, and $\mathrm{RH} 93 \%$ with $\mathrm{CO}_{2}$. To maintain the ambience conditions of dry $\mathrm{CO}_{2}, \mathrm{RH} 15 \%$ with $\mathrm{CO}_{2}$ and $\mathrm{RH} 93 \%$ with $\mathrm{CO}_{2}$, the dry silica gel, saturated aqueous $\mathrm{LiCl}$ and $\mathrm{NaHCO}_{3}$ solutions are placed below the samples, respectively. After that, the containers are filled with $\mathrm{CO}_{2}$. The $\mathrm{RH} 18 \%$ (without $\mathrm{CO}_{2}$ ) atmosphere was obtained by placing the saturated $\mathrm{NaOH}$ solution at the bottom of the container and then filled with dry $\mathrm{O}_{2}$. The accurate $\mathrm{RH}$ is determined by a hygrometer, whose accuracy is $\pm 1 \%$. The elemental compositions of pristine and exposed samples were confirmed by inductively coupled plasma-atomic emission spectrometry (ICP-AES) analysis (IRIS Intrepid II XSP, Thermo Electron). Before ICP-AES and Time-of-flight secondary ion mass spectroscopy (TOF-SIMS) testing, we applied a scavenging process to remove the $\mathrm{Na}_{2} \mathrm{CO}_{3} / \mathrm{NaHCO}_{3}$ byproducts in the exposed samples. Specifically, the exposed samples were immersed and stirred in distilled water for $3 \mathrm{~min}$, then centrifuged and dried at $80^{\circ} \mathrm{C}$ overnight.

Characterizations. The X-ray diffraction (XRD) patterns were obtained on a Rigaku Ultima IV diffractometer by a Persee instrument with $\mathrm{Cu} \mathrm{Ka}$ radiation $(\lambda=1.5406 \AA)$. The patterns were refined by the General Structure Analysis System (GSAS) software ${ }^{44}$. The morphologies of samples were characterized by scanning electron microscopy (SEM, Hitachi S-4800). The EDS elemental mapping experiments were conducted using FEI Talos-F200s TEM instrument. The ${ }^{23} \mathrm{Na}$ ss-NMR experiments were acquired on a Bruker AVANCE III $400 \mathrm{MHz}$ spectrometer using a double resonance $1.3 \mathrm{~mm}$ MAS probe spinning at frequencies of up to $55 \mathrm{kHz}$ with a Hahn-echo pulse sequence (i.e. $90^{\circ}$ pulse $-\tau-180^{\circ}$ pulse $-\tau$, where $\tau$ is set to a multiple of rotor periods). The $90^{\circ}$ pulse length of $1.2 \mu \mathrm{s}$ and a recycle delay of $2 \mathrm{~ms}$ were used. The ${ }^{23} \mathrm{Na}$ shifts were referenced to $1 \mathrm{M} \mathrm{NaCl}$ aqueous solution $(0$ ppm). For ${ }^{1} \mathrm{H}$, the $2.5 \mathrm{~mm}$ MAS probe was used spinning at $25 \mathrm{kHz}$ to record the ${ }^{1} \mathrm{H}$ spectra with the rotor-synchronized Hahn Echo sequence and a cycle delay of $2 \mathrm{~s}$ and $\mathrm{a} 90^{\circ}$ pulse length of $4 \mu \mathrm{s}$. No window functions were added and the chemical shift of ${ }^{1} \mathrm{H}$ was referenced against adamantane $(1.87 \mathrm{ppm})$. By using $2.5 \mathrm{~mm}$ MAS probe with a MAS rate of $25 \mathrm{kHz}$, the rotational echo double resonance (REDOR) NMR sequence (i.e. the rotor-synchronized Hahn echo is applied on ${ }^{23} \mathrm{Na}$, during $\tau$ periods the ${ }^{23} \mathrm{Na}-{ }^{1} \mathrm{H}$ dipolar coupling is recovered by $180^{\circ}{ }^{1} \mathrm{H}$ pulses) is applied to confirm the presence of $\mathrm{H}^{+}$in the exposed materials. Geometry-independent information about the ${ }^{23} \mathrm{Na}-{ }^{1} \mathrm{H}$ dipole couplings can be conveniently obtained from the plot of signal attenuation (1-scale) versus the dipolar evolution time (2tau). In all MAS NMR measurements, the variable temperature (VT) gas temperature was set to $315 \mathrm{~K}$. The in situ XRD experiments were performed in air and on a BrukerD8 Discover diffractometer equipped with a $\mathrm{Cu}$ $\mathrm{Ka}$ radiation. Infrared spectra were recorded on a Nicolet is50 FT-IR (Thermo
Fisher Scientific Inc., Madison, USA) spectrometer. X-ray absorption spectroscopy (XAS) data were acquired in the transmission mode at the BL14W1 beamline of the Shanghai synchrotron radiation facility (SSRF) at room temperature, and the incident beam was monochromatized by a Si (111) double-crystal monochromator. TOF-SIMS were performed on a TOF-SIMS5 spectrometer (ION TOF GmbH). The depth profiling and high-resolution mapping were conducted at the high current mode and burst alignment mode, respectively, with a pulsed $\mathrm{Bi}_{1}{ }^{+}$ion beam $(30 \mathrm{keV})$. The sputtering was conducted by a $500 \mathrm{eV} \mathrm{Cs}^{+}$ion beam with the area of $100 \mu \mathrm{m} \times$ $100 \mu \mathrm{m}$, and the analyzed areas for depth profiling and high-resolution mapping are typically $100 \mu \mathrm{m} \times 100 \mu \mathrm{m}$ and $50 \mu \mathrm{m} \times 50 \mu \mathrm{m}$ with the pixel of $128 \times 128$.

Electrochemical tests. The electrodes are composed of $80 \mathrm{wt} \%$ of active materials, $10 \mathrm{wt} \%$ of polyvinylidene fluoride (PVDF) and $10 \mathrm{wt} \%$ acetylene carbon black. The mass loading of active materials is $2.5-3 \mathrm{mg} \mathrm{cm}^{-1}$. The cleaned aluminum foil was used as current collector. The electrochemical performances were tested in 2025 coin cells which assembled in an Ar-filled glove box, using $1 \mathrm{M} \mathrm{NaPF}_{6}$ in Propylene carbonate (PC, $98 \mathrm{vol} \%$ ) and Fluoroethylene carbonate (FEC, $2 \mathrm{vol} \%$ ) as the electrolyte, Whatman glass fiber filter as the separator, and sodium metal as the counter electrode. The galvanostatic charge-discharge processes were conducted on multichannel battery tester (Neware, CT-4008-5V10mA-164). The electrochemical impedance spectroscopy (EIS) was conducted by a four-channel multifunctional electrochemical workstation (Versa STAT MC. America), at the cell voltage of $4.0 \mathrm{~V}$ and with the frequency range of $100 \mathrm{kHz}$ to $0.01 \mathrm{~Hz}$.

DFT calculation. The DFT calculations were performed on VASP (Vienna ab initio Simulation Package $)^{66}$ and the exchange-correlation interactions of electron were described with spin-polarized generalized gradient approximation (GGA) and parameterized by PBE formula ${ }^{67}$. The projector-augmented wave approach and GGA + U method were used to evaluate the electron-ion interactions and the localization of the d electrons of the TM ions, respectively 68,69 . The $U$ value of $\mathrm{Mn}$ set to $3.9 \mathrm{eV}$ and the wave functions were expended by plane wave with a kinetic energy cut-off of $520 \mathrm{eV}$. The Monkhorst-Pack scheme ${ }^{70}$ was used for the integration in the irreducible Brillouin zone with a k-point mesh resolution of $2 \pi \times$ $0.025 \AA^{-1}$. The lattice parameters and atomic coordinates were fully relaxed, and the final forces on all atoms were $<0.01 \mathrm{eV}^{-1}$. For the DFT calculations, a $3 \times 3 \times$ 1 supercell, which contains $12 \mathrm{Na}, 36 \mathrm{O}$, and $18 \mathrm{Mn}$ has been adopted. Sodium contents of $x=0.667,0.556,0.500,0.444$ and 0.389 in $\mathrm{Na}_{\mathrm{x}} \mathrm{MnO}_{2}$ correspond to 12 , $10,9,8$ and $7 \mathrm{Na}$ ions in the supercell, and the number of different structures for each Na contents is $C_{12}^{0}, C_{12}^{2}, C_{12}^{3}, C_{12}^{4}$, and $C_{12}^{5}$, respectively. Therefore, 1574 kinds of structures should be considered based on the enumeration method. Such computation load is however too heavy to be carried out and 9 of them have been calculated. Specifically, we considered two different sodium extraction models for the five different $\mathrm{Na}$ contents. The number of calculated structures for $x=0.667$ $0.556,0.500,0.444$ and 0.389 in $\mathrm{Na}_{\mathrm{x}} \mathrm{MnO}_{2}$ are 1, 2, 2, 2, 2, respectively, as shown in Fig. 4f (page 11 in the manuscript). Moreover, the residual $\mathrm{Na}$ sites were chosen randomly and then one water molecule was put into an empty $\mathrm{Na}$ site also randomly.

\section{Data availability}

All relevant data that support the findings of this study are presented in the manuscript and supplementary information file. Source data are available from the corresponding author on request.

Received: 18 January 2020; Accepted: 18 June 2020; Published online: 15 July 2020

\section{References}

1. Whittingham, M. S. Ultimate limits to intercalation reactions for lithium batteries. Chem. Rev. 114, 11414-11443 (2014).

2. Yabuuchi, N., Kubota, K., Dahbi, M. \& Komaba, S. Research development on sodium-ion batteries. Chem. Rev. 114, 11636-11682 (2014).

3. Nayak, P. K., Yang, L., Brehm, W. \& Adelhelm, P. From lithium-ion to sodium-ion batteries: advantages, challenges, and surprises. Angew. Chem. Int. Ed. 57, 102-120 (2018)

4. Vaalma, C., Buchholz, D., Weil, M. \& Passerini, S. A cost and resource analysis of sodium-ion batteries. Nat. Rev. Mater. 3, 18013 (2018).

5. Wang, P.-F., You, Y., Yin, Y.-X. \& Guo, Y.-G. Layered oxide cathodes for sodium-ion batteries: phase transition, air stability, and performance. $A d v$ Energy Mater. 8, 1701912 (2018).

6. Newman, G. H. \& Klemann, L. P. Ambient temperature cycling of an Na-TiS cell. J. Electrochem. Soc. 127, 2097-2099 (1980).

7. Delmas, C., Braconnier, J., Fouassier, C. \& Hagenmuller, P. Electrochemical intercalation of sodium in $\mathrm{Na}_{\mathrm{x}} \mathrm{CoO}_{2}$ bronzes. Solid State Ion. 3-4, 165-169 (1981). 
8. Zuo, W. et al. Structure-performance relationship of $\mathrm{Zn}^{2+}$ substitution in $\mathrm{P} 2-\mathrm{Na}_{0.66} \mathrm{Ni}_{0.33} \mathrm{Mn}_{0.67} \mathrm{O}_{2}$ with different $\mathrm{Ni} / \mathrm{Mn}$ ratios for high-energy sodiumion batteries. ACS Appl. Energy Mater. 2, 4914-4924 (2019).

9. Yabuuchi, N. et al. P2-type $\mathrm{Na}_{\mathrm{x}}\left[\mathrm{Fe}_{1 / 2} \mathrm{Mn}_{1 / 2}\right] \mathrm{O}_{2}$ made from earth-abundant elements for rechargeable Na batteries. Nat. Mater. 11, 512-517 (2012).

10. Kumakura, S., Tahara, Y., Kubota, K., Chihara, K. \& Komaba, S. Sodium and manganese stoichiometry of $\mathrm{P} 2$-type $\mathrm{Na}_{2 / 3} \mathrm{MnO}_{2}$. Angew. Chem., Int. Ed. 55, 12760-12763 (2016).

11. $\mathrm{Xu}, \mathrm{K}$. Electrolytes and interphases in $\mathrm{Li}$-ion batteries and beyond. Chem. Rev. 114, 11503-11618 (2014)

12. Zuo, W. et al. Sodium storage behavior of $\mathrm{Na}_{0.66} \mathrm{Ni}_{0.33-\mathrm{x}} \mathrm{Zn}_{\mathrm{x}} \mathrm{Mn}_{0.67} \mathrm{O}_{2}(\mathrm{x}=0$, 0.07 and 0.14 ) positive materials in diglyme-based electrolytes. J. Power Sources 400, 317-324 (2018).

13. Fang, C. et al. Routes to high energy cathodes of sodium-ion batteries. Adv. Energy Mater. 6, 1501727 (2016).

14. Shadike, Z. et al. Advanced characterization techniques for sodium-ion battery studies. Adv. Energy Mater. 8, 1702588 (2018).

15. Clément, R. J., Bruce, P. G. \& Grey, C. P. Review-manganese-based P2-type transition metal oxides as sodium-ion battery cathode materials. $J$. Electrochem. Soc. 162, A2589-A2604 (2015).

16. Lu, Z. \& Dahn, J. R. In situ X-ray diffraction study of $\mathrm{P} 2-\mathrm{Na}_{2 / 3} \mathrm{Ni}_{1 / 3} \mathrm{Mn}_{2 / 3} \mathrm{O}_{2}$. J. Electrochem. Soc. 148, A1225 (2001).

17. Somerville, J. W. et al. Nature of the "Z"-phase in layered Na-ion battery cathodes. Energy Environ. Sci. 12, 2223-2232 (2019).

18. Wang, Q. C. et al. Tuning P2-structured cathode material by Na-site $\mathrm{Mg}$ substitution for Na-ion batteries. J. Am. Chem. Soc. 141, 840-848 (2018).

19. Wu, X. et al. P2-type $\mathrm{Na}_{0.66} \mathrm{Ni}_{0.33-\mathrm{x}} \mathrm{Zn}_{\mathrm{x}} \mathrm{Mn}_{0.67} \mathrm{O}_{2}$ as new high-voltage cathode materials for sodium-ion batteries. J. Power Sources 281, 18-26 (2015).

20. Zhang, J., Wang, W., Wang, W., Wang, S. \& Li, B. Comprehensive review of P2-type $\mathrm{Na}_{2 / 3} \mathrm{Ni}_{1 / 3} \mathrm{Mn}_{2 / 3} \mathrm{O}_{2}$, a potential cathode for practical application of Na-ion batteries. ACS Appl. Mater. interfaces 11, 22051-22066 (2019).

21. Clément, R. J. et al. Structurally stable $\mathrm{Mg}$-doped $\mathrm{P} 2-\mathrm{Na}_{2 / 3} \mathrm{Mn}_{1-\mathrm{y}} \mathrm{Mg}_{\mathrm{y}} \mathrm{O}_{2}$ sodium-ion battery cathodes with high rate performance: insights from electrochemical, NMR and diffraction studies. Energy Environ. Sci. 9, 3240-3251 (2016).

22. Liu, $\mathrm{X}$. et al. $\mathrm{P} 2-\mathrm{Na}_{0.67} \mathrm{Al}_{\mathrm{x}} \mathrm{Mn}_{1-\mathrm{x}} \mathrm{O}_{2}$ : cost-effective, stable and high-rate sodium electrodes by suppressing phase transitions and enhancing $\mathrm{Na}+$ mobility. Angew. Chem., Int. Ed. 58, 18086-18095 (2019).

23. Zuo, W. et al. Highly-stable $\mathrm{P} 2-\mathrm{Na}_{0.67} \mathrm{MnO}_{2}$ electrode enabled by lattice tailoring and surface engineering. Energy Storage Mater. 26, 503-512 (2020).

24. Zheng, S. et al. Exploring the working mechanism of $\mathrm{Li}^{+}$in O3-type $\mathrm{NaLi}_{0.1} \mathrm{Ni}_{0.35} \mathrm{Mn}_{0.55} \mathrm{O}_{2}$ cathode materials for rechargeable $\mathrm{Na}$-ion batteries. $J$. Mater. Chem. A 4, 9054-9062 (2016).

25. Boyd, S., Dhall, R., LeBeau, James, M. \& Augustyn, V. Charge storage mechanism and degradation of P2-type sodium transition metal oxides in aqueous electrolytes. J. Mater. Chem. A 6, 22266-22276 (2018)

26. You, Y., Dolocan, A., Li, W. \& Manthiram, A. Understanding the air-exposure degradation chemistry at a nanoscale of layered oxide cathodes for sodium-ion batteries. Nano Lett. 19, 182-188 (2019).

27. Lu, Z. \& Dahn, J. R. Intercalation of water in P2, T2 and $\mathrm{O} 2$ Structure $\mathrm{A}_{\mathrm{z}}\left[\mathrm{Co}_{\mathrm{x}} \mathrm{Ni}_{1 / 3-\mathrm{x}} \mathrm{Mn}_{2 / 3}\right] \mathrm{O}_{2}$. Chem. Mater. 13, 1252-1257 (2001).

28. Duffort, V., Talaie, E., Black, R. \& Nazar, L. F. Uptake of $\mathrm{CO}_{2}$ in layered P2$\mathrm{Na}_{0.67} \mathrm{Mn}_{0.5} \mathrm{Fe}_{0.5} \mathrm{O}_{2}$ : insertion of carbonate anions. Chem. Mater. 27, 2515-2524 (2015).

29. Zhang, Y., Zhang, R. \& Huang, Y. Air-stable $\mathrm{Na}_{\mathrm{x}} \mathrm{TMO}_{2}$ cathodes for sodium storage. Front. Chem. 7, 335 (2019).

30. Han, M. H. et al. Moisture exposed layered oxide electrodes as Na-ion battery cathodes. J. Mater. Chem. A 4, 18963-18975 (2016).

31. $\mathrm{Mu}, \mathrm{L}$. et al. Prototype sodium-ion batteries using an air-stable and $\mathrm{Co} / \mathrm{Ni}$-free O3-layered metal oxide cathode. Adv. Mater. 27, 6928-6933 (2015).

32. Yan, Z. et al. A hydrostable cathode material based on the layered P2@P3 composite that shows redox behavior for copper in high-rate and long-cycling sodium-ion batteries. Angew. Chem., Int. Ed. 58, 1412-1416 (2019).

33. Guo, S., Li, Q., Liu, P., Chen, M. \& Zhou, H. Environmentally stable interface of layered oxide cathodes for sodium-ion batteries. Nat. Commun. 8, 135 (2017).

34. Chen, T. R. et al. $\mathrm{Cu}^{2+}$ dual-doped layer-tunnel hybrid $\mathrm{Na}_{0.6} \mathrm{Mn}_{1-\mathrm{x}} \mathrm{Cu}_{\mathrm{x}} \mathrm{O}_{2}$ as a cathode of sodium-ion battery with enhanced structure stability, electrochemical property, and air stability. ACS Appl. Mater. interfaces 10, 10147-10156 (2018).

35. $\mathrm{Mu}$, L. et al. Water-processable $\mathrm{P} 2-\mathrm{Na}_{0.67} \mathrm{Ni}_{0.22} \mathrm{Cu}_{0.11} \mathrm{Mn}_{0.56} \mathrm{Ti}_{0.11} \mathrm{O}_{2}$ cathode material for sodium ion batteries. J. Electrochem. Soc. 166, A251-A257 (2019).

36. Ching, S., Landrigan, J. A. \& Jorgensen, M. L. Sol-gel synthesis of birnessite from $\mathrm{KMnO}_{4}$ and simple sugars. Chem. Mater. 7, 1604-1606 (1995).

37. Ching, S., Petrovay, D. J., Jorgensen, M. L. \& Suib, S. L. Sol-gel synthesis of layered birnessite-type manganese oxides. Inorg. Chem. 36, 883-890 (1997).
38. Bach, S., Pereira-Ramos, J. P., Baffier, N. \& Messina, R. Birnessite manganese dioxide synthesized via a sol-gel process: a new rechargeable cathodic material for lithium batteries. Electrochim. Acta 36, 1595-1603 (1991).

39. Kubota, K. \& Komaba, S. Review-practical issues and future perspective for na-ion batteries. J. Electrochem. Soc. 162, A2538-A2550 (2015).

40. Liu, H., Yang, Y. \& Zhang, J. Reaction mechanism and kinetics of lithium ion battery cathode material $\mathrm{LiNiO}_{2}$ with $\mathrm{CO}_{2}$. J. Power Sources 173, 556-561 (2007).

41. Pritzl, D. et al. Editors' choice-washing of nickel-rich cathode materials for lithium-ion batteries: towards a mechanistic understanding. J. Electrochem. Soc. 166, A4056-A4066 (2019).

42. Bianchini, M., Roca-Ayats, M., Hartmann, P., Brezesinski, T. \& Janek, J. There and back again-the journey of $\mathrm{LiNiO}_{2}$ as a cathode active material. Angew. Chem., Int. Ed. 58, 10434-10458 (2019).

43. Jung, R. et al. Effect of ambient storage on the degradation of Ni-rich positive electrode materials (NMC811) for Li-ion batteries. J. Electrochem. Soc. 165, A132-A141 (2018).

44. Toby, B. H. EXPGUI, a graphical user interface for GSAS. J. Appl. Cryst. 34, 210-213 (2001).

45. Han, M. H. et al. High-performance P2-phase $\mathrm{Na}_{2 / 3} \mathrm{Mn}_{0.8} \mathrm{Fe}_{0.1} \mathrm{Ti}_{0.1} \mathrm{O}_{2}$ cathode material for ambient-temperature sodium-ion batteries. Chem. Mater. 28, 106-116 (2016).

46. Takada, K. et al. Superconductivity in two-dimensional $\mathrm{CoO}_{2}$ layers. Nature 422, 53-55 (2003)

47. Onda, A., Hara, S., Kajiyoshi, K. \& Yanagisawa, K. Synthesis of manganese oxide octahedral molecular sieves containing cobalt, nickel, or magnesium, and the catalytic properties for hydration of acrylonitrile. Appl. Catal., A 321, 71-78 (2007).

48. Gullion, T. \& Schaefer, J. Detection of weak heteronuclear dipolar coupling by rotational-echo double-resonance nuclear magnetic resonance. Adv. Magn. Optical Reson. 13, 57-83 (1989).

49. Wu, X. et al. Insights into the effects of zinc doping on structural phase transition of P2-type sodium nickel manganese oxide cathodes for highenergy sodium ion batteries. ACS Appl. Mater. Interfaces 8, 22227-22237 (2016).

50. Rana, J. et al. Structural changes in $\mathrm{Li}_{2} \mathrm{MnO}_{3}$ cathode material for Li-ion batteries. Adv. Energy Mater. 4, 1300998 (2014).

51. Ball, M. C., Snelling, C. M., Strachan, A. N. \& Strachan, R. M. Thermal decomposition of solid sodium sesquicarbonate, $\mathrm{Na}_{2} \mathrm{CO}_{3} \cdot \mathrm{NaHCO}_{3} \cdot 2 \mathrm{H}_{2} \mathrm{O}$. J. Chem. Soc., Faraday Trans. 88, 631-636 (1992).

52. Dutcher, B. et al. Use of nanoporous FeOOH as a catalytic support for $\mathrm{NaHCO}_{3}$ decomposition aimed at reduction of energy requirement of $\mathrm{Na}_{2} \mathrm{CO}_{3} / \mathrm{NaHCO}_{3}$ based $\mathrm{CO}_{2}$ separation technology. J. Phys. Chem. C. 115, 15532-15544 (2011).

53. $\mathrm{Li}$, Y. et al. Air-stable copper-based $\mathrm{P} 2-\mathrm{Na}_{7 / 9} \mathrm{Cu}_{2 / 9} \mathrm{Fe}_{1 / 9} \mathrm{Mn}_{2 / 3} \mathrm{O}_{2}$ as a new positive electrode material for sodium-ion batteries. Adv. Sci. 2, 1500031 (2015).

54. Rong, X. et al. Structure-induced reversible anionic redox activity in $\mathrm{Na}$ layered oxide cathode. Joule 2, 125-140 (2018).

55. Maitra, U. et al. Oxygen redox chemistry without excess alkali-metal ions in $\mathrm{Na}_{2 / 3}\left[\mathrm{Mg}_{0.28} \mathrm{Mn}_{0.72}\right] \mathrm{O}_{2}$. Nat. Chem. 10, 288-295 (2018).

56. Kang, W. et al. Copper substituted P2-type $\mathrm{Na}_{0.67} \mathrm{Cu}_{\mathrm{x}} \mathrm{Mn}_{1-\mathrm{x}} \mathrm{O}_{2}$ : a stable highpower sodium-ion battery cathode. J. Mater. Chem. A 3, 22846-22852 (2015)

57. Hamani, D., Ati, M., Tarascon, J.-M. \& Rozier, P. $\mathrm{Na}_{\mathrm{x}} \mathrm{VO}_{2}$ as possible electrode for Na-ion batteries. Electrochem. Commun. 13, 938-941 (2011).

58. Mortemard de Boisse, B. et al. Intermediate honeycomb ordering to trigger oxygen redox chemistry in layered battery electrode. Nat. Commun. 7, 11397 (2016).

59. Perez, A. J. et al. Strong oxygen participation in the redox governing the structural and electrochemical properties of Na-rich layered oxide $\mathrm{Na}_{2} \mathrm{IrO}_{3}$. Chem. Mater. 28, 8278-8288 (2016).

60. Komaba, S., Takei, C., Nakayama, T., Ogata, A. \& Yabuuchi, N. Electrochemical intercalation activity of layered $\mathrm{NaCrO}_{2}$ vs. $\mathrm{LiCrO}_{2}$. Electrochem. Commun. 12, 355-358 (2010).

61. Yabuuchi, N., Yoshida, H. \& Komaba, S. Crystal structures and electrode performance of alpha- $\mathrm{NaFeO}_{2}$ for rechargeable sodium batteries. Electrochemistry 80, 716-719 (2012).

62. Dai, K. et al. High reversibility of lattice oxygen redox quantified by direct bulk probes of both anionic and cationic redox reactions. Joule 3, 518-541 (2019).

63. Zheng, L., Li, J. \& Obrovac, M. N. Crystal structures and electrochemical performance of air-stable $\mathrm{Na}_{2 / 3} \mathrm{Ni}_{1 / 3-\mathrm{x}} \mathrm{Cu}_{\mathrm{x}} \mathrm{Mn}_{2 / 3} \mathrm{O}_{2}$ in sodium cells. Chem. Mater. 29, 1623-1631 (2017).

64. Wang, Q et al. Reaching the energy density limit of layered O3$\mathrm{NaNi}_{0.5} \mathrm{Mn}_{0.5} \mathrm{O}_{2}$ electrodes via dual $\mathrm{Cu}$ and $\mathrm{Ti}$ substitution. Adv. Energy Mater. 9, 1901785 (2019).

65. Greenspan, L. Humidity fixed points of binary saturated aqueous solutions. $J$. Res. Natl Bur. Stand. Sect. A: Phys. Chem. 81A, 89 (1977). 
66. Kresse, G. \& Furthmuller, J. Efficient iterative schemes for ab initio totalenergy calculations using a plane-wave basis set. Phys. Rev. B Condens Matter 54, 11169-11186 (1996).

67. Perdew, J. P., Burke, K. \& Ernzerhof, M. Generalized gradient approximation made simple. Phys. Rev. Lett. 77, 3865-3868 (1996).

68. Kresse, G. \& Joubert, D. From ultrasoft pseudopotentials to the projector augmented-wave method. Phys. Rev. B 59, 1758-1775 (1999).

69. Anisimov, V. I., Aryasetiawan, F. \& Lichtenstein, A. First-principles calculations of the electronic structure and spectra of strongly correlated systems: the LDA+ U method. J. Phys.: Condens. Matter 9, 767 (1997).

70. Monkhorst, H. J. \& Pack, J. D. Special points for Brillouin-zone integrations. Phys. Rev. B 13, 5188-5192 (1976).

\section{Acknowledgements}

This work is financially supported by National Key Research and Development Program of China (grant no. 2018YFB0905400, 2016YFB0901502, 2016YFA0202602), National Natural Science Foundation of China (grant no. 21761132030, 21935009, 51972257). G.F. Ortiz acknowledges the Spanish Ministry of Science and Innovation (grant no. MAT2017-84002-C2-1-R and PRX18/00463). Dr. R. Fu thanks to the support from the National High Magnetic Field Laboratory, which is supported by NSF Cooperative Agreement NSF/DMR-1644779 and the State of Florida. Jimin Qiu acknowledges the grant from the National Science Fund for Fostering Talents in Basic Science (No. J1310024). We thank Dr. Jiaxin Ding in the Instrumental Analysis Center, Shanghai Jiao Tong University for her contribution in the TOF-SIMS analysis. We gratefully acknowledge the valuable time from beamline BL14W1 of the Shanghai Synchrotron Radiation Facility (SSRF).

\section{Author contributions}

W.Z., J.Liu, and Y.Y. conceived the project. Y.Y. supervised the project. W.Z., J.Q., J.Liu., M.W., Y.L., R.F., and Y.Y. designed the experiments. W.Z. and J.Q. performed the materials synthesis and electrochemical testing. W.Z., J.Q., X.L., H.H., H.L., C.L., and J.Li, performed the characterizations. F.R. completed the computational calculations. W.Z., J.Q., X.L., F.R., G.F.O., H.D., J.Liu, Y.L., R.F, and Y.Y., analyzed the data and proposed the mechanisms. W.Z., J.Liu, R.F., and Y.Y., wrote the initial paper. All authors discussed the results and commented on the paper.

\section{Competing interests}

The authors declare no competing interests.

\section{Additional information}

Supplementary information is available for this paper at https://doi.org/10.1038/s41467020-17290-6.

Correspondence and requests for materials should be addressed to J.L. or Y.Y.

Peer review information Nature Communications thanks the anonymous reviewers for their contribution to the peer review of this work.

Reprints and permission information is available at http://www.nature.com/reprints

Publisher's note Springer Nature remains neutral with regard to jurisdictional claims in published maps and institutional affiliations.

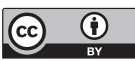

Open Access This article is licensed under a Creative Commons Attribution 4.0 International License, which permits use, sharing, adaptation, distribution and reproduction in any medium or format, as long as you give appropriate credit to the original author(s) and the source, provide a link to the Creative Commons license, and indicate if changes were made. The images or other third party material in this article are included in the article's Creative Commons license, unless indicated otherwise in a credit line to the material. If material is not included in the article's Creative Commons license and your intended use is not permitted by statutory regulation or exceeds the permitted use, you will need to obtain permission directly from the copyright holder. To view a copy of this license, visit http://creativecommons.org/ licenses/by/4.0/.

(C) The Author(s) 2020 